TREASURY DEPARTMENT UNITED STATES PUBLIC HEALTH SERVICE

PUBLIC HEALTH BULLETIN No. 84 DECEMBER, 1916

\title{
IS MOSQUITO OR MAN THE WINTER CARRIER OF MALARIA ORGANISMS?
}

\author{
By \\ M. BRUIN MITZMAIN \\ Technical Assistant, United States Public Health Service
}

PREPARED BY DIRECTION OF THE SURGEON GENERAC
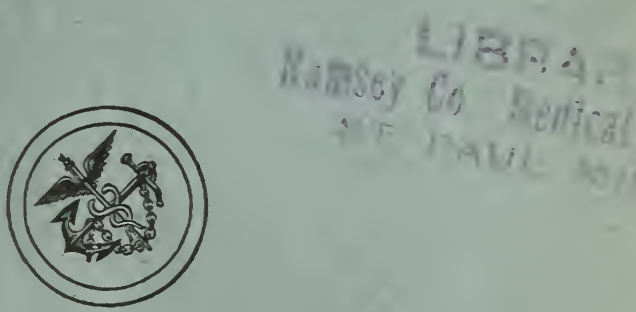

WASHINGTON

GOVERNMENT PRINTING OFFICE 



\title{
PUBLIC HEALTH BULLETIN No. 84
} DECEMBER, 1916

\section{IS MOSQUITO OR MAN THE WINTER CARRIER OF MALARIA ORGANISMS?}

\author{
By \\ M. BRUIN MITZMAIN \\ Technical Assistant, United States Public Health Service
}

PREPARED BY DIRECTION OF THE SURGEON GENERAL

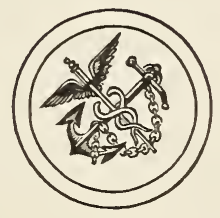

WASHINGTON

GOVERNMENT PRINTING OFFICE 
ADDITIONAL COPIES

OF THIS PUBLICATION MAY BE PROCCRED FROM THE SUPERINTEXDENT OF DOCTMEXTS

GOVERNMENT PRINTING OFFICE

WASHINGTON, D. C.

AT

10 CENTS PER COPY 


\section{L L U S TR A T I O S.}

FIG. 1. Map showing indiridual plantations of the Mississippi Delta Planting Co.

2. Upturned root mass of fallen tree where a few specimens of A. quadrimaculatus were found amongst the exposed root fibers on March 28.

3. Excaration made by falling tree exposing roots, pool of water beneath. Here, in February and March, culicines were found in larral and pupal stages and emergences obserred. Anopheles absent.

4, 5. Method of searching hollows in standing and fallen timber for hibernating forms. The tree shown in figure 5 was seen to harbor many Anopheles in September, 1914.

6. A hole in a hollow tree receiring sulphur dioxide fumigation.

7. Showing understructure of plantation houses, which are found to be fruitful sources of hibernating Anopheles.

8. Showing understructure of plantation houses, which were found to be fruitful sources of hibernating Anopheles.

9. Dr. M.'s house, showing means of access by mosquitoes through lattice work and holes in brick understructure. Under this house the first hibernating Anopheles were collected during the first week of February.

10. Typical cypress trunk with fissured structure in which leares found lodgment to serve as possible hiding places for resting anophelines. Such places were not found to shelter mosquitoes.

11. Canvas-corered canoe, which remained undisturbed during fall and winter. Shows the ripped canras in the end of the canoe where sereral inches of water remained. No mosquitoes of any stage were seen.

12. Showing the method adopted by use of horses as bait to attract anophelines in the roods.

13. An inundated "borrow pit" on Whitehall plantation. Anopheles larræ were not found here during February.

14. Junction of Deer Creek and Lake Bolivar, where in late fall larræ and pupæ of A. quadrimaculatus were found. Seren persons among the fishing women on the bridge proved to be winter carriers of Plasmodium.

15. Group of negro tenants on Lake Vista plantation. No case of sickness reported here, set 43 per cent were carriers of malaria during February and March.

16. Group of tenants on Mrers plantation. 50 per cent were infected with malaria during February and March. No clinical case observed. The head of the family prored to be a gamete carrier.

17. Showing apparently healthy negro tenants of Mound plantation engaged in clearing operations. Fire of the eight men in this picture were winter carriers of malaria; two of these harbored gametocytes.

18. Photomicrograph of a stained preparation showing roung oocysts on the stomach of an A. quadrimaculatus dissected May 15, 1915. This represents the initial infection of the spring season.

19. Enlarged view of portion of figure 1 . 



\title{
IS MOSQUITO OR MAN THE WINTER CARRIER OF MALARIA ORGANISMS?
}

\author{
By M. Bruin Mrtzmain, Technical Assistant, United States Public Health \\ Service.
}

The potential hosts, mosquito and man, were studied to determine the carrier responsible for the perpetuation of the malaria organism during the inactive period of winter. An effort was made to show where the causative agent of malaria remains latent in localities having a dormant season, during which the anopheline mosquitoes hibernate. The results of this study are given herewith. The solution of the problem is aimed at because its economic importance appears to be not inconsiderable, judging from the discussion devoted to it by many writers on malaria epidemiology.

\section{LITERATURE.}

The arailable references in the literature on this problem of hibernation are as follows:

Herms (1915) has given probably the best exposition of the relationship of man and mosquito in regard to the question, "How does the malaria parasite overwinter?" He is quoted as follows:

"Since malaria has a typical seasonal occurrence, with little or no appearance during the winter months, the question arises, Does the parasite overwinter in its human host to break out in the spring in individual cases by the process of parthenogenesis, or does it overwinter in the body of the mosquito? The weight of evidence is against the latter possibility. The writer believes ihat the Anopheles mosquito seldom or ever takes a suck of blood before going into hibernation. A suck of blood would militate against the life of the mosquito inasmuch as it causes the development and ultimate extrusion of ora and that terminates the life of the insect. Other physiological reasons, involving further increased metabolism, seem to discount the possibility of successful hibernation. Furthermore, the writer has seen great numbers of voracious Anopheles in the spring both indoors and out, and has been frequently bitten by these as have many others without becoming infected. These hibernated individuals on coming out early in the spring bite viciously even at noonday. Furthermore, evidence that infected mosquitoes exist during the winter months seems to be lacking or has been overlooked.

"On the other hand, latent human infection has been amply proved, and this may easily lead to the infection of the mosquitoes appearing in the early spring and thus lead to the spread of malaria as the season adrances." 
Evidently, there is some disagreement among certain authors in accounting for the recrudescence of malaria during the winter.

Stephens (1908) states that the recurrence of isolated cases of new infections with malaria in Italy during winter and spring is attributed to the agency of the hibernating anophelines. In the early months some of these may fly abroad, as early as February on warm dars, and further, as Koch pointed out, in certain houses where dnopheles exist the temperature is high enough to allow the derelopment of the parasite in the mosquito. "One fact, howerer, has not been established, that these hibernating anophelines actually do contain sporozoites in their salivary glands: and in fact, according to Schoo, of Holland, they do not. MacDonald's observations in Spain were also negative in this respect."

Manson (1901), with his usual insight, sums up his knowledge of the problem in stating that in countries in which there is a cold season, during which fresh malarial infections do not take place, the infection of the next warm season is probably, in most instances, started from a relapse of a previous infection. "It has not been shown that the malarial parasite can retain its vitality in the mosquito during the hibernation of this insect."

And again Manson (1914) explains the improbability of sporogonic cycle under circumstances of libernation by the statement that one of the most important conditions necessary to the sporogonic phase of the malaria germ is a sustained average temperature of at least $60^{\circ} \mathrm{F}$. " The malaria parasite wlll not develop in the mosquito at low temperatures."

Deaderick (1911) expresses his views as follows: "How is the existence of the malaria parasite perpetuated? Why does the disease become extinct over winter when there are apparently no mosquitoes to further the life history of the organism?" He believes that it is possible that in a few instances the parasites persist in the bodies of hibernating mosquitoes. "While some investigators have led to a different conclusion Martirano found in the neighborhood of Rome. as late as the middle of March, that from one-fifth of 1 per cent of Anopheles rere infected." Deaderick concludes that latent or chronic malaria will furnish the solution.

Henson (1913), writing of the limitation of the rôle of wintering Anopheles, states that, relative to climatic conditions. it has already been shown that in many sections of the world following the winter months malaria has been eradicated, and that before mosquitoes are again capable of producing the infection in man it is necessary for them to feed on the blood of infected manthat is, blood containing the sexual forms of the parasite.

Mitchell (1907), on the authority of Dr. Johnson, believes that the malaria parasites have their winter quarters in the human body, because the female mosquitoes do not make a meal before hiberuating. These, howerer, quoting Dr. Smith, may bite during the winter in a warm house.

Smith (190t) describes the conditions applicable to the State of Ner Jerser as follows: "Breeding of Anophclcs goes on until Norember in mild season, but early in October, or even in late September, specimens begin to seek hiberuating quarters. As the insects do not feed before doing this, the malarial organism can not be carried orer br them. The germ lies dormant in the human blood, and, in a partly cured case, there may be no active symptoms of the disease, while ret the gametes or reproductive bodies are present. Such cases as these Italian laborers hare started malarial trouble in sereral New Jersey localities theretofore exempt."

Scheube (1902) summarizes the views of several authors relative to hibernation as follows: "It therefore follows that the same kind of mosquito may be 
harmless at a low temperature but mav become dangerous when the temperature rises. The mosquitoes in zones of moderate heat are driven into houses, huts, stables, etc., during the winter, and the parasites then perish. In the spring, howerer, the mosquitoes reinfect themselves from patients who are suffering from relapses, which, thus as it were, form the connecting link, the bridge between the fever time of one year and that of the next."

Scheube states that Celli and Del Peno found in the Campagna that the ferers of March to the end of June were relapses of former infections; that toward the end of June, the first infected Anopheles were found, and their number increased in July and August.

The foremost American sanitarians regard the question of continuance of infection by means of hibernating mosquitoes as unsettled.

Von Ezdorf (1915) writes as follows: "Mosquitoes do not bite, and are inactive when a temperature of $15.5^{\circ} \mathrm{C}$. or less is reached. At this or lower temperature the mosquitoes begin to hibernate, finding protection in garrets, under houses, in hollows of trees, etc., but if the weather should moderate and become quite warm, as happens in our southern States, the mosquitoes may again become active; it is known that endemic outbreaks of malaria have occurred in the winter months, but whether due to infected hibernating mosquitoes or to relapses is not known. It has not yet been definitely determined whether the infected hibernating mosquito carries orer the infection from winter until spring.

"In the winter months cases of malaria which occur are usually relapses from previous infections. The influence of cold in these relapses produces a lowering of the vitality in the individuals, and thus favors the renewed inrasion of the parasite."

Craig (1909) is quoted as follows: "In temperate and cold regions they may pass through the cold season as fully dereloped adults, as larvæ, or even in the ova. According to Theobald, the fertilized females of A. maculipennis hibernate in the adult stage in cellars, outhouses, stables, etc., while $A$. bifurcatus and $A$. nigripes exist throughout the winter in the larval stage eren under thick ice. If a warm spell occurs during a winter some of the hibernating mosquitoes emerge from their hiding places and bite, thus causing outbreaks of malaria during the winter season."

Regarding the hibernation of the rarious stages of Anopheles in a restricted biological sense, a review of the literature is giren as follows :

Patten and Cragg (1913), alluding to the longerity and perpetuation of the anophelines, state that the commonest method by which this is brought about is by the hibernation of impregnated females, which, finding the season too far adranced to complete the maturation and deposition of their ora, seek out resting places and remain concealed until favorable conditions present themselres at the commencement of the next season.

Nuttall and Shiples (1901) cite that A. quadrimaculatus is recorded by Grassi as congregating during the winter in houses, huts, and barns in southern and central Italy. Only the imagines are found and no larræ. The larræ of A. bifurcatus were found in these localities. Grassi assumed that these latter may not have hibernated but were derired from late-laid eggs.

Nuttall and Shipley, commenting on their own work, state that in laboratory experiments in England larræ collected in summer were allowed to derelop; that, while those of $A$. bifurcatus remained alive during the winter, all the larræ of A. quadrimaculatus died. They remark that "whether the larræ of A. quadrimaculatus are capable of hibernating or not can not be positirely stated, although it would appear unlikely, judging from our observations and those of Grassi." 
Nuttall found that $A$. quadrimaculatus, which hibernated in the winter in Cambridge, was observed to disappear in May, "no doubt to oviposit and then to die."

Grassi (in Nuttall and Shipley, 1902) says that he has never found the males of A. maculipennis hibernating but only the females, all of these being fecundated. They begin to disappear in February, in Italy, and vanish to a greater extent in March when at times none are to be found. These insects have, presumably, flown out and died after depositing their eggs.

Austen (1901) cites his observations in England as follows: "In colder climates, on the other hand, impregnated females survive the winter in some suitable retreat in a state of hibernation, during which they take no food, depositing their eggs at the commencement of warmer weather."

Annett and Dutton (1901) in the course of their observations on the hiberna. tion of English mosquitoes never found any of the mosquitoes in stables and cattle sheds, as these places were comparatively dry and warmed by the animals at night. Not a single male A. maculipennis was seen during several months in the winter. This fact they interpret as indicating that it is the female alone that hibernates.

Stephens (1908), writing on the length of Anopheles life, states: "It was originally supposed that mosquitoes, when they had laid their eggs, died. The observations are, however, probably true of these mosquitoes which have hibernated during the winter (in a fecundated state). On the return of spring they sally forth and lay their eggs and die."

Stephens assumed that the hibernating Anopheles are all females and these are always fertilized; that the females, if roused from their sluggishness by bringing them into a warm room, will feed, and after a time lay eggs; if, however, the temperature be kept low, they do not arouse themselves and do not feed.

Giles (1902), referring to the seasonal inactivity of Anopheles, states that this habit is spoken of as hibernation, and in Europe, where the males apparently all die before winter has fairly set in, only impregnated females survive the winter, "and it is through their agency alone that the continuity of the species is maintained."

Howard, Dyar, and Knab (1912), are quoted as follows: "With the majority of the species of mosquitoes the unfarorable season is passed in the egg state. Certain genera, howerer, pass the winter in the adult state. In such cases it is only the female that survives, having been previously fertilized, to deposit her eggs at the beginning of another season. It is certain that, at least in the genera Culex and Anopheles, no males survive the winter. The hibernating females seek shelter with the approach of cold weather, and at this time they show no inclination to feed. Those species more or less associated with man take advantage of the shelter of cellars, stables, sheds, and other outbuildings, the darkest ones apparently being the most favored. They have also been found hibernating in caves. Other species retire to hollows in trees, crevices in the bark, or other protected situations. There they remain quiescent until the return of the warm weather, closely hugging the surface upon which they rest."

Rosenau (1913) remarks: "The way in which mosquitoes manage to pass through the rigors of the winter probably varies with the different species. Some, like the malarial Anopheles, hide in sheltered cellars or dark nooks, or hibernate in other out-of-the-way places. Other species survire through the power of the larva or egg to resist cold, for the larræ or eggs of some species will hatch even after they have been frozen." 
Shipley (1915), writing of the eggs of the A. quadrimaculatus, states: "There is no evidence that they can surrire throughout the winter period. Everything that we know indicates that the egg must pass the period within the mother's body, and that they only attain maturity in early spring, when the weather becomes warmer."

It will be noted that there is a marked unanimity of expression indicating the belief that the mosquito phase of the overwintering of malaria is a negligible factor. These opinions are, to be sure, based on epidemiological data and show a uniform absence of experimental proof. Howerer logical these expressions appear to be, the fact remains that the problem can not be dismissed as settled until further experimental data are presented.

OUTLINE OF WORK.

At the outset of the present work it was necessary to secure data contributing toward the solution of the following: In what habitat in the region under observation did anopheline mosquitoes hibernate? When did this occur, and under what limitations? In what form (egg, larva, pupa, or adult) did anopheline mosquitoes pass the winter? What were the effects of temperature on the activities of the hibernating mosquitoes? Lastly, did anopheline mosquitoes harbor any form of the malaria organism during the dormant stage?

A persistent effort was made, during February to June, 1915, to collect as much data concerning these points as was possible.

A district comprising 15 plantations of the Mississippi Delta Planting Co., in Bolivar and Washington Counties of northwestern Mississippi, was selected for the purpose of this study by Surg. R. H. von Ezdorf, in charge of malaria investigations of the Public Health Service until his death in September, 1916.

In a general way the places inspected were those known to have harbored Anopheles mosquitoes during the season when malaria was prevalent. The plantations selected for domiciliary risits were the most heavily infected of the 15 plantations, the malaria index registering, at one place at least, as high as 58 per cent in September, 1914. The following record gives the details as to the character of the places visited and the opportunities for infestation presented. Routine inspections were conducted in this manner for a period of six weeks, beginning February 5, 1915. During the first two weeks the writer had the cooperation of Sanitary Engineer Le Prince, who was assigned to field studies. His notes are incorporated in the account appended.

NOTES ON FIELD EXAMINATIONS.

February 5, 1915.-Examined interior of buildings and outhouses connected with Dr. M.'s residence. They included ice house and harness room, which were very dark and tight (wind proof), but accessible to mosquitoes. The former $66681^{\circ}-16-2$ 
was found with one opening, about 6 by 2 feet, partially protected by a torn screen about $\mathbf{5}$ feet from the ground, one entry door, alwass closed when not in use. Ice house contained cotton sacks, boards leaning against the wall, and empty boxes and barrels. The harness room was well constructed (size 4 by 6 by 10 feet), wind proof, but would admit mosquitoes at all times. We examined the stable, containing cotton sacks, boards, exposed shingle roof, cornstalks used as bedding for stock, underside of feed trough in mangers, high and low rafters, and ceiling of shingles above them.

One old abandoned barn east of Dr. M's house contained a flat-bottomed boat and wooden canoe with canvas compartments. The floor of this structure was corered with cornstalks about one to two inches deep; it was not used except for storage of unserviceable waste and such odds and ends as old stores, tin cans, large and small bottles, loose wire screen, boxes, worn-out storepipe, and two baby carriages. These were stacked in a disorderly heap in the corner of the building in a pile about 8 by $S$ by 4 feet high and offered many excellent hiding places for mosquitoes. The flat-bottom boat had the rear seat boxed in for a length of 2 feet; a board of this box was torn off, so that its inside compartments might be carefully inspected-results negative. The canoe was interesting and offered excellent wind shelter for mosquitoes. We ripped open the canvas compartments and took a photograph of the boat. While this was being done, it was noted that water 6 inches in depth filled the lower end. 'The stored canoe was resting at about $30^{\circ}$ to the horizontal, so that water collected at the pointed end of one of the compartments. Anopheline larvæ were absent.

About a quarter of a mile from the house we examined the grove of trees surrounded by cotton fields. We examined the interior of six large hollow trees-one was 4 feet wide inside-also the interior of 15 hollow logs and 22 live trees with big vines growing on them. The trees were buttressed at the trunk, offering excellent wind shelter. The rines had diameters up to 2 inches and many hairy roots to grasp the tree's bark and would afford an insect much protection. One oak tree had hollows in upper portion of roots and they were examined by striking matches and illuminating the interior.

Next, examined negro cabin-back, inclosed porch with lots of stuff stored, including parts of wooden bed which were leaning up in a corner, and cracks between logs of back wall of house inside of balcony-then examined corn storage shed with wooden shingle roof. Results negative.

February 6.-Examined the premises of plantation manager, Mr. R. L. The residence was inspected within and under, and the near-by barn was likewise inspected. It was noted that a leafy rine, suitable for mosquito harborage, covered the sides and roof of the main building. Two large animal sheds with moss-corered roofs were examined. A small bell tower near cow barn also receired attention. The inspection included a near-by cotton gin and warehouses. Mosquitoes were absent generally.

February \%.-Spent the entire day in wood and crpress and oak swamp near Dr. M's estate. At the present time the swamp is being drained and the woods cleared. During the summer of 1914, a moderate number of Anopheles larvæ were collected in this swamp. We inspected the contents and surroundings of 72 crpress and oak trees and stumps with loose bark and worm-eaten interiors, many partly hollow and in a state of collapse. These were torn apart for more careful examination, as they offered numerous excellent hiding places for mosquitoes. Te found piles of leares in some instances heaperl to the trunks and crotches and covering fallen logs. These were examined minutely. The loose bark on cypress stumps was observed to be so placed as to afford excellent shelter from rain, sun, and wind. A special effort was made to ascertain the 
presence of hibernating mosquitoes in this seemingly farorable enrironment, but all search was fruitless, although 17 harborages of this nature were carefully scanned. In mans of the cut trees the roots were submerged in a natural basin of water, suppyling moisture to about one-third the length of the interior of the hollow stump. In other stumps, decomposing in the interior, the tops were found to be open so that the interior of the tree stump formed a natural tube to which the rain had access. In still others, which were hollow to a considerable distance, ther were entirely protected from the rain and moistened only from rain-soaked soil at the roots. Many stumps, seemingly sound externally with solid bark, were rotted in the interior, and had numerous channels made by burrowing insects, and holes made by owls, woodpeckers, and rabbits, thus seeming to furnish conditions attractire to resting mosquitoes. In many of these the entire bark was cautiously stripped to expose the interior, when the holes and air spaces were minutels inspected. Other trees mere carefully inspected for mosquito infestation; some old trees with hollows exposed to the wind found isolated in cotton and corn fields, as well as trees and stumps in the interior and on the edges of the sramp; also the tree stumps and trees in the heart of the dry woods. The hollows of some of these trees extended into the roots, the spaces of which were prodded with sticks. Also 22 fallen trees had their bark remored, and the surrounding accumulation of leares and mood pulp were well scrutinized. No mosquitoes were seen in these natural environments, though ther were apparently suitable resting places, and indeed, in sereral of the places inspected, mosquitoes had been found previously during the time of mosquito actirity.

February 8.-It was noted that as late as 7.30 a. m.. there was a coating of one-eighth to one-fourth inch of ice in the road side ditches.

Inspected the environs of a large frame building, fitted up as a general store and post office. The interior, which was dark in the early morning, was seen by the aid of an electric flash light and an oil lantern. Here numerous situations, ordinarily farorable to mosquitoes, were encountered. The building was unusually dark at all times, the only sources of light being obstructed by broken shutters fastened securels. The ordinary accumulation of empts barrels and boxes glutted the arailable storage space. Sereral of these rere superimposed, so that the lower as well as the upper one was accessible to mosquitoes. Empty sacks in the corners and loose boards leaning against the wall, as well as a large empty piano packing case, were inspected. The racant spaces, on 36 feet lengths of shelring and under the numerous counters, were examined carefully, with negative results. An adjoining wreck of an abandoned barn, once utilized as a blacksmith shop, but now inhabited bs a famils of swine, was giren careful consideration, with no better results.

Following this the interiors of nine negro cabins were examined. All of the inhabitants agreed that mosquitoes were not found in their houses during the cold season. These persons were offered 25 cents for each mosquito found during our visit and subsequentls, but without return. We inspected the cracks in these log houses, under shelring, under loose wall paper. the wooden ceiling, and sacking suspended therefrom, also furniture, beds, and loose boxes littered about the floors. The inspection included the underside of these houses. No mosquitoes were found.

February 9.-Ice about 8 a. m., melted by 9 a. m., warm at noon-about $14.5^{\circ} \mathrm{C}$. to $15.5^{\circ} \mathrm{C}$. in shade.

Caught the first mosquito since arrival. Sereral (9) captured in short time under the house of Dr. M. at 2 to $2.35 \mathrm{p}$. m. Captured sis on north side of house, some flying away at our approach and settling again near bs; two 
of these escaped by flying away from the house. Two mosquitoes were captured on strands of cobweb. One was taken while resting on brick support. The remainder were collected from surface of wood, usually near a moist place.

Inspected Eastland estate, 2 miles north of Scott. Under the manager's residence the entire flooring was inspected. In this particular locality in September, 1914, Mr. Le Prince had counted as many as 30 Anopheles to the meter. Two chimney supports under the house were likewise inspected, but no mosquitoes were found. The sereral outhouses, horse shed, and has loft yielded nothing. Four hollow trees were examined; two were subjected to sulphur dioxide fumigation. This was done by spreading white paper over the ground inside of the tree; bricks were placed on this supporting an iron pot containing sulphur and alcohol. Stiff paper, held in place by boards, effectively covered the opening. The hollow in these trees extended fully 15 feet, so that it was necessary to apply the sulphur fumes for a long period. After sereral hours the pot was withdrawn and paper and interior of tree were inspected, but no mosquitoes were found. The only living things seen were six small, stupified flies, collected from the laver of paper.

February 10.- Inspected a large number of houses on Belmont plantation. Several Anopheles were taken in the bright light under the plantation manager's house; most of these were seen on the flooring near the walls.

The first general mosquito infestation was noticed on February 11, beginning at 4.30 p. m., in the woods of Mound plantation. Here, while making an inspection trip with three other horsemen, Anopheles were observed biting our horses, particularly on the sides exposed to direct sunlight. It was noted that the flight was from northeast; that there was a moderate breeze from the southwest; and that the nearest settlement, comprising 45 dwellings, lay approximately threeeighths of a mile to the west, the direction apparently selected by the voracious mosquitoes.

Large numbers of mosquitoes were observed to be coming from the general direction of the depth of the woods, where the company's main drainage ditch was located. Prior to this time, and subsequently, at least once weekly for a period of three months, this body of water was scrupulously explored for any young forms of Anopheles. Immediately following the general infestation. a special and conscientious effort was made to iocate empty puparia, to account for the emergence of such a swarm of mosquitoes. Absence of these or other young forms was invariably the rule.

On the following day, February 13, mosquitoes were still present in considerable numbers, but few were found a month thereafter. In fact, a relatively warm day was required to induce biting, although horses were used to bait the mosquitoes. Between March 6-13, only 14 Anopheles were collected from two plantations, but the two following days proved to be warmer, when 69 specimens were collected from a horse used for the purpose. Biting the horse did not begin usually until nearly 3 p. m. upon these and sereral other occasions. The mosquitoes were seen to come from the direction of the near-by 
swamp, attacking the horse on the side away from the swamp, biting in the sunlight.

It appears that some resting place other than under dwellings must be offered, to account for the hibernation of the swarms of anophelines which infest this locality during warm days in winter and in early spring. Sereral of these sites were actually deroid of resting mosquitoes, although the residents complained of them during warm spells. A notable example of this paucity of material was found in a residence inspected at Nugent plantation, about 4 miles north of Scott. Here the manager's residence, a commodious, substantially constructed, frame house, was examined on February 18. The house was situated about 50 meters from some swamp land, which was formed by the orerflow of Lake Bolivar. The structure presented a floor space of fully 486 square feet of solid boarding. The height from the ground was 2 feet 6 inches, surrounded on all sides but one by latticework forming holes $1 \frac{3}{4}$ inches in size. The remaining side was made of an unbroken brick wall. The supports, numbering $\check{5}$,

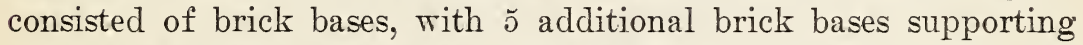
the fireplaces abore. Fire wooden stairways must also be mentioned, as ordinarily these shelter mosquitoes. At the time of examination the ground beneath the house was fairly dry, but corered with tin cans and dried leares. Under the dwelling there was ample light to see the boarding surface and brick supports. No mosquitoes were found in any of these places. The swamp in front of the house was deroid of young mosquito life.

In this region the nearest approach to a house cellar was found, February 16, in the form of a dirt storm cellar, built alongside the residence adjoining an old ground cistern. Here no mosquitoes were found, although seemingly ideal shelter was offered. This is significant, because rarious authors state that house cellars offer good locations for hibernation.

Some clue as to the resting places of anophelines during early spring was afforded on the morning of March 28, while I was in the oak woods examining the upturned roots of a fallen tree. A few mosquitoes were noticed flying about in the light. one of which, an A. quadrimaculatus, was caught biting $\mathrm{my}$ hand. It was examined subsequently and prored to be negatire for suspicious organisms. Sereral of the actire mosquitoes alighted on the moist root hairs of the dead tree. A bird dog was induced to nose about the holes in the matted roots, with the result that it attracted the attention of sereral ricious $A$. quadrimaculatus. It was noticed that a small pool was formed in the excarated earth under the root mass, and here a moderate number of culicine larræ were collected. Neither eggs nor larvæ of Anopheles were present. 
Again, earlier in March while in the interior of the woods exposing myself to the attacks of Anopheles. I dislodged some mosquitoes from a young cypress tree. Upon closer examination I observed an $A$. quadrimaculatus female resting among the twigs. For sereral hours I repeated this experiment, rigorously shaking young trees in the cypress brake, and counted sereral mosquitoes. apparently anophelines, which were dislodged from their resting places. On the two following afternoons I brought a saddle horse to an open place near the cypress brake and in 30 minutes succeeded in collecting 24 Anopheles that alighted on the horse.

The evidence offered from the investigation thus far would seem to indicate that the majority of the mosquitoes captured probably hibernated in the denser portion of the woods. Here, protection from unfavorable conditions of temperature, winds, and moisture would be better assured. Doubtless, with suitable rise of temperature, anophelines become active, biting men and horses in the woods, being transported in a measure by these natural rehicles out of the woods to the near-by dwellings. Here they would again seek shelter, selecting the most suitable substitute for trees, namely, the large timbers under the flooring of the house, where moisture, darkness, and wind protection could be obtained. Here, upon the understructures, the anophelines were discovered in a quiescent state, the degree of dormancy depending on the time of day and the temperature. By the aid of the electric torchlight, these mosquitoes were studied under many houses, beginning early in the morning and throughout the day. From a dormant, sprawling condition in the cold forenoons, a gradual change of attitude and location was noted. Incidentally it was observed that the well-known attitude of "sprawling" was rarely assumed when the temperature was above $9.0^{\circ} \mathrm{C}$. The usual attitude of the two species, A. quadrimaculatus and $A$. punctipennis, under the dwelling was seen to be with the body held nearly parallel to the perpendicular plane, close to the flooring with the head directed upward and the caudal end slightly raised. When the weather became slightly warmer, or when disturbed from the normal attitude, the mosquitoes were found suspended from above, nearly at right angles to the flooring.

A perceptible shifting toward the warmer and lighter side of the house was observed as the morning progressed. By remaining quiet for 30 minutes or longer, the observer was a ware that the mosquitoes shifted from the understructures to the open spaces below. One would fly a meter or two, alighting on a beam near the outer wall of the house. If the weather toward noon was distinctly warmer, mosquitoes were seen to fly from beneath the dwelling into the open and in the direction apparently of the nearest trees. 
On April 11 there was noted for the first time a perceptible disappearance of Anopheles from the woods, and coincidentally the resumption of normal parasitism, biting in the evening rather than in daylight. This was ascertained by a trip on horseback covering $1 \pm$ miles through the woods and swamps. The horses were rested at frequent intervals, especially in regions where the greatest number of mosquitoes were collected previously. Only a fer specimens of Culex and Simulium were captured.

The normal nocturnal biting habit was brought to the attention of the writer by the manager of Myers plantation along Bolivar Lake, a few miles north of Scott. Complaints of biting at night, and the presence of numerous anophelines in the corner of the screened house gallery, were definite proofs. This occurred during the last week of April and on May 2. It was assumed by the manager that the stiff breezes of recent occurrence drore mosquitoes which emerged from the waters of Kentucky Shoot, on the opposite side of Lake Bolivar, to the plantation manager's house, a distance of 400 meters.

A survey was therefore instituted to ascertain, if possible, the source of the Anopheles infestation on Myers plantation. A day was occupied in a small skiff, inspecting Lake Bolivar in the region of Kentucky Shoot. It was found that the latter was a shallow bayou 10 meters in width at its maximum, extending 500 meters through Isole plantation. Dense cypress extended on both sides of the stream, the head of which formed a stagnant swamp draining a ditch from an adjoining cotton field. The open woods along the banks of the shoot formed a pasturage for animals, seen grazing at the time of our surrey. Near the mouth of the shoot, in the matted algæ and débris, a few Aedes larvæ were found. This form only was encountered for a distance of $7 \check{0}-100$ meters, then larræ of Anopheles predominated for a distance of 60 meters. An arerage of one specimen of Anopheles larva to two dipperfuls of water was collected. During the entire period of the inspection, Aedes bit us freely, but not a single instance of Anopheles biting was observed along the shoot or in the woods near by. While in the pasture land a few Anopheles were caught biting us and a grazing pony.

It was concluded from the two days' survey that some source other than Kentucky shoot was responsible for the Anopheles infestation across the lake at Myers plantation.

In the collection of 308 Anopheles made at Myers plantation at this time (on or before May 2) only specimens of females were caught, and these, in the majority of instances, showed oraries distended with eggs. It was concluded, therefore, that the spring brood was not in existence before May 2, and that the mosquitoes encountered were probably, without exception, from the overwintered brood. 
It was established beyond a reasonable doubt that the new spring brood was not likely to have received the initial infections of malaria. Certainly the females of the winter brood had greater opportunities to obtain human blood to the extent of at least tro meeks antedating the appearance of the spring brood. During May 4-10 a special effort was made to collect specimens of the spring brood attacking persons in houses. Many houses of both whites and negroes mere risited during this period and the writer exposed himself in an unscreened plantation house in order to collect specimens at first hand. In all this, while not a specimen of male Anopheles was seen, the females dissected were either fecund with dereloped eggs or supplied with masses of fat cells, indicative of matured mosquitoes.

In this search it was particularly noted that the mosquitoes prevalent observed their natural habits of biting and in the usual house infestation. In one morning's collecting 60 specimens of Anopheles quadrimaculatus were taken from a negro cabin located on the edge of a swampy woods. The residents, nearly all of whom had been previously infected with malaria, complained that the mosquitoes were so bad at nights as to interfere with sleep and that it was found necessary to resort to smudging. In the kitchen of this dwelling the smoke was very dense; here no mosquitoes were found.

As in previous collecting, no male Anopheles were observed, and many of the females were grarid and laid fertile eggs when kept in containers a few dars previous to their dissection in the laboratory.

In one negro cabin typical epidemiological factors were presented. The house, of two living rooms, was occupied by 12 persons, 1 at least had crescents in her blood and at least 5 of the remainder harbored asexual parasites. The house was 300 meters distant from the neighbor's on the edge of a clearing in the woods, which in winter is ordinarily very strampy. The nearest trees were 25 meters away. The cabin and adjoining forl roost yielded 145 specimens of A. quadrimaculatus. More than 100 were collected in a single room; 36 of them from behind one of the beds in which a child was then sleeping. A ladder was used to obtain the mosquitoes from the walls and ceiling. The walls were constructed of rough pine boarding and the ceiling of close-fitting finished lumber. No whitewash, as it is commonly seen, was used in this room. The mosquitoes were, for the most part, resting on objects of furniture, particularly upon the three bedsteads in the corners. A black umbrella alongside the bed yielded 3 mosquitoes, the headboard of a bed yielded $\bar{r}$, a spider web near the ceiling yielded 6 , and the fireplace within the chimney yielded 12 mosquitoes. Many of these mosquitoes were seen upon the ceiling after being disturbed below. Sereral specimens were taken from the bed net which corered the sleeping child. The forl roost yielded 35, and 9 were taken from beneath the cabin. The dis- 
tribution of the 145 mosquitoes was as follows: 35 in the chicken house, 9 under the cabin, 101 within the cabin.

In order definitely to establish the fact that hibernation of Anopheles exists in this region certain conditions must be present. These would include the absence of propagation during the cold period; certainly no emergences should exist, or, obriously, the criterion for the overwintering of infections will be upset. The presence of eggs and young larvæ will somewhat complicate the findings unless it can be proved that these forms are lying dormant during the entire winter; otherwise certain calculations will be upset by the forthcoming new brood.

The absence of males appears to establish what is probably the most stable criterion of hibernation, or at least one which gives a certain indication that a new brood is not present. It has been observed, upon numerous occasions, and by other workers, that the product of the first emergences are usually males, and that the total number of the two sexes is approximately equal.

All of the eridence that it is possible to offer in this connection favors the assumption that the mosquitoes obtained in the months of February, March, and April are of the fall and winter brood.

In addition to this, a painstaking and persistent search was conducted for the eggs, larvæ, and pupæ of Anopheles throughout the watercourses and swamps of the 15 plantations situated in Bolivar and Washington Counties. Not before May 1 were Anopheles larvæ taken from the natural habitats, although larvæ were obtained under artificial conditions in the laboratory on April 21. These were produced from a specimen of Anopheles quadrimaculatus, caught while biting my arm on April 6 while in the roods. The specimen was captured and fed again April 10. It died April 16 while ovipositing, having laid 10 eggs in a glass dish containing water. The eggs hatched after five days, at an average noon temperature of $23.5^{\circ}-26^{\circ} \mathrm{C}$. This, howerer, is by no means a true index of what occurs in nature, as it has been possible to remore gravid females from a profound state of hibernation in cold weather and, after a meal of blood, to induce them to lay fertile eggs at room temperature. Certain inferences, howerer, may be drawn from this phenomenon, namely, that, unless we concede a parthenogenetic relationship, the hibernating females are doubtless fertilized sometime previous to the inactire period; that the males no longer functioning do not hibernate, that the appearance of males in the spring is a certain sign of the propagation of the spring generation.

The initial appearance of the young stages in nature occurred May 2, when larvæ less than twice the length of the egg were collected in several watercourses. Larræ, in numbers enough to attract attention, did not occur until May 14, when they were found during a 
survey of Black Swamp Bayou, on Lake Bolivar plantation, and Gin Bayou, on Nugent plantation. On the former location an ideal habitat was afforded among trees and floatage carelessly thrown into the stream. Many larræ, one-half to nearly full grown, were collected on this day and only one pupa was seen. On May 15 this pupa emerged in the laboratory as a specimen of a male A. quadrimaculatus.

A moderate number of water containers used as traps, distributed throughout several plantations, were utilized in an endearor to learn the time of initial egg laying and hatching. These were selected, primarily, either for the reason that larræ had been observed in them in the previous fall and winter or because they were located in advantageous places. The containers were usually stationary vessels, some of which were filled with water, which was allowed to stand undisturbed; in others the water was replenished when necessary. They consisted of wooden water barrels, old boats or canoes serring as water troughs, old wooden drinking troughs full of rain water, iron cisterns, cement water troughs, fire buckets and barrels, and numerous ground cisterns. At least one of these was located on each of the various plantations and inspected regularly at intervals of from three to four days during the months of February, March, and April, when evidences of mosquitoes were absent from natural watercourses.

None of these produced eggs or larræ until May 25, when, for the first time in this region, two large water barrels were found infested. One barrel contained 30-40 larva, 1 to a few days old, and the other harbored older larva to the extent of $20-25$ specimens. It appears that container infestation generally follows propagation in watercourses. In two instances at least was this observed; one in which an old boat alongside a muddy ditch was not infested until two weeks following the appearance of full grown larve in the latter. and another in which wooden barrels kept on a house gallery 25 meters from a flowing stream did not harbor larræ until 11 days following the infestation of the watercourse.

The finding of Anopheles eggs in streams under natural environments is conceded to be a difficult task, even when mosquito propagation is at its maximum, but the difficulties are manifold when attempting to locate these tiny objects during the winter period. The effort met with uniform failure, though, allowing for human limitation, Anopheles eggs may have been orerlooked in the present studies.

As a partial control to this condition, experiments were conducted in the laboratory, apart from the hibernation inrestigation, during August 20 to October 15, 1915, to determine at what temperature Anopheles lay eggs and the nature of temperature requirements for their hatching. 
The following table summarizes the results of these tests. "The mosquitoes used were Anopheles quadrimaculatus placed in various compartments of two refrigerators, the temperature being carefully registered three times a day. The mosquitoes were captured specimens kept in lantern chimneys, the upper ends of which were closed with coarse bobinet and the lower ends immersed in water contained in flat dishes. The higher temperatures were secured from an electrically controlled, low-temperature incubator set at $19-21^{\circ} \mathrm{C}$. and from living room and outdoor exposures at temperatures of $16-35^{\circ} \mathrm{C}$.

TABLE No. I.-Summarizing the results of egg production and hatching at various temperatures.

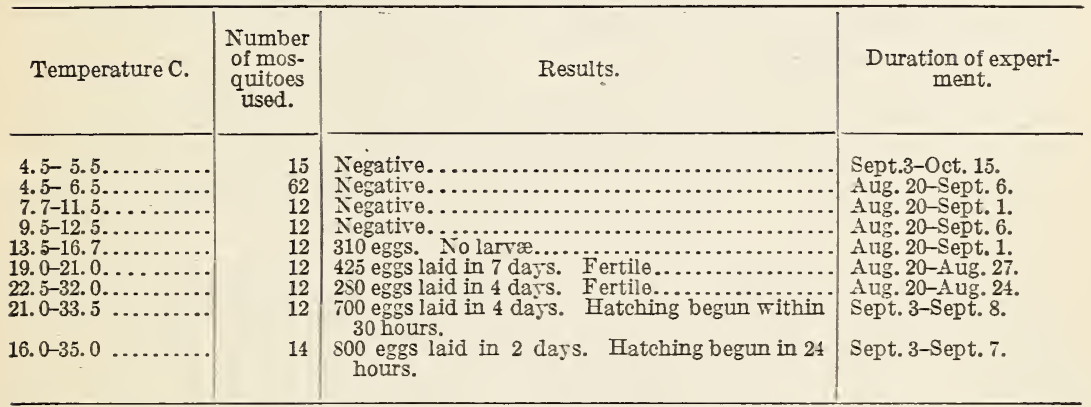

The temperature tests were conducted during the period from August 20 to October 15, 1915. No cognizance is taken of the fate of the mosquitoes after egg deposition was completed. Interpretation of results in some instances must allow for the unpreparedness of females to lay eggs, although they were kept a reasonable length of time to encourage egg development. Therefore no significance is placed on the percentage of eggs laid at the different temperatures. As a check to the negative results obtained at temperatures included between $5.5^{\circ}-12.5^{\circ} \mathrm{C}$., the mosquitoes surviving at the termination of the tests rere subjected to temperatures at which successful egg laying had been previously observed. These farorable temperatures were obtained in the room or outdoors varying from $16^{\circ}$ to $35^{\circ} \mathrm{C}$. Although eggs were laid freely their germinating powers were markedly enfeebled, since only 35 per cent to 75 per cent of the various lots produced larræ.

It will be noticed that the temperatures $13.5^{\circ}-16.7^{\circ} \mathrm{C}$. produced 310 eggs, but no larvæ, at the end of 12 days. The fertility of these eggs was tested in the incubator at a temperature of $19^{\circ}-21^{\circ}$ C., when 100 per cent of them hatched within 48 hours.

It must be borne in mind that the conditions of these tests are strictly artificial, especially in subjecting mosquitoes to ice-cooled air when directly removed from much higher outdoor temperature. Probably a fairer test, simulating natural conditions, would obtain in a gradual fall or rise in temperature. This was indicated in one 
experiment where 3 mosquitoes, which had not laid eggs at a temperature of $3^{\circ}-6.5^{\circ}$ C. for one week, were transferred accidentally to another compartment of the refrigerator where the temperature registered $9^{\circ}-12^{\circ} \mathrm{C}$. Six hours elapsed before the misplaced cage was discorered, when it was noticed that about $i 0$ eggs had been deposited. No more eggs were laid when the mosquitoes were returned to the low temperature compartment and the eggs subjected to room temperature did not hatch. This phenomenon might be applied to natural conditions of hibernation in which. during the normal low temperature of winter, a rise of $2.5^{\circ}-5.5^{\circ} \mathrm{C}$. would afford an opportunity for Anopheles to oriposit.

The temperatures recorded during the hibernation studies are tabulated as follows:

TABLE No. II.-Temperatures and rainfall during January-May, 1915.

(Recorded at office of Mississippi Delta Planting Co.)

\begin{tabular}{|c|c|c|c|c|c|c|c|c|c|}
\hline \multirow{2}{*}{ Week. } & \multicolumn{3}{|c|}{ January. } & \multicolumn{3}{|c|}{ February. } & \multicolumn{3}{|c|}{ March. } \\
\hline & $\begin{array}{l}\text { Mini- } \\
\text { mum. }\end{array}$ & $\begin{array}{l}\text { Maxi- } \\
\text { mum. }\end{array}$ & Mean. & $\begin{array}{l}\text { Mini- } \\
\text { mum. }\end{array}$ & $\begin{array}{l}\text { Maxi- } \\
\text { mum. }\end{array}$ & Mean. & $\begin{array}{l}\text { Mini- } \\
\text { mum. }\end{array}$ & $\begin{array}{l}\text { Maxi- } \\
\text { mum. }\end{array}$ & Mean. \\
\hline 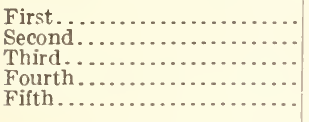 & $\begin{array}{l}-2.5 \\
-2.0 \\
-1.5 \\
-5.5 \\
-1.5\end{array}$ & $\begin{array}{l}17.0 \\
14.0 \\
19.0 \\
17.0 \\
19.0\end{array}$ & $\begin{array}{l}6.5 \\
5.5 \\
6.5 \\
1.5 \\
4.0\end{array}$ & $\begin{array}{r}-1.5 \\
0.0 \\
1.5 \\
3.0\end{array}$ & $\begin{array}{l}15.0 \\
21.0 \\
16.0 \\
20.0\end{array}$ & $\begin{array}{r}7.0 \\
10.5 \\
10.5 \\
7.0\end{array}$ & $\begin{array}{r}0.5 \\
2.0 \\
-0.5 \\
-3.0 \\
1.0\end{array}$ & $\begin{array}{l}17.5 \\
14.0 \\
1 S .5 \\
19.5 \\
20.5\end{array}$ & $\begin{array}{r}7.0 \\
6.5 \\
5.5 \\
8.5 \\
10.5\end{array}$ \\
\hline $\begin{array}{l}\text { Monthly rainfall } \ldots \ldots \ldots \ldots \\
\text { Snow ............................ }\end{array}$ & \multicolumn{3}{|c|}{$\begin{array}{l}3.64 \\
0.67\end{array}$} & \multicolumn{3}{|c|}{$\begin{array}{c}5.56 \\
\ldots .6 .\end{array}$} & \multicolumn{3}{|c|}{$\begin{array}{c}1 . \Omega_{3} \\
\ldots . . .\end{array}$} \\
\hline \multirow{2}{*}{\multicolumn{4}{|c|}{ Week. }} & \multicolumn{3}{|c|}{ A pril. } & \multicolumn{3}{|c|}{ May. } \\
\hline & & & & $\begin{array}{l}\text { Mini- } \\
\text { mum. }\end{array}$ & $\begin{array}{l}\text { Maxi- } \\
\text { mum. }\end{array}$ & Mean. & $\begin{array}{l}\text { Mini- } \\
\text { mum. }\end{array}$ & $\begin{array}{l}\text { Maxi- } \\
\text { mum. }\end{array}$ & Mean. \\
\hline \multirow{2}{*}{\multicolumn{4}{|c|}{ 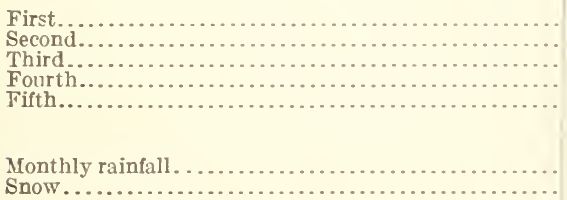 }} & $\begin{array}{r}2.0 \\
10.0 \\
12.0 \\
1.5 .0 \\
19.5\end{array}$ & $\begin{array}{l}25.5 \\
2 \varsigma .0 \\
31.0 \\
32.0 \\
34.0\end{array}$ & $\begin{array}{l}12.0 \\
20.0 \\
20.5 \\
23.5 \\
26.0\end{array}$ & $\begin{array}{l}15.5 \\
12.0 \\
15.5 \\
18.5 \\
12.5\end{array}$ & $\begin{array}{l}32.0 \\
31.0 \\
34.0 \\
33.5 \\
29.0\end{array}$ & $\begin{array}{l}23.5 \\
19.5 \\
25.0 \\
26.0 \\
21.0\end{array}$ \\
\hline & & & & \multicolumn{3}{|c|}{0.40} & \multicolumn{3}{|c|}{$\begin{array}{r}5.57 \\
\ldots .\end{array}$} \\
\hline
\end{tabular}

Collateral studies conducted January 3-9. 1916, at Talladega springs, Ala.. a fairly well isolated country town, furnished us with the following information. At this place the investigation was not made primarily for the study of malaria hibernation, but incidental to securing specimens of anophelines for biting experiments. One week was spent at this place, the nature of which differs in one important particular from that of the locality investigated in Mississippi, the presence of commodious, substantially built animal sheds. These places were found to harbor more than 50 per cent of the total number of Anophcles collected. This condition has also been observed in other localities in the South by service officers making malaria survess during the winter months. Possibly the predilection of anophelines for the blood of cattle aur horses may exert an influence on the loss of malarial infectivity of these insects 
during the orerwintering period. A mosquito which mar enter upon the hibernating stage in an infectire state and which confines its biting to animals housed for the winter may clear its salivary glands of sporozoites before it again bites a human being.

A few notes concerning conditions of hibernation at Talladega Springs were made in the course of collecting specimens during January 3-9, 1916 . An examination was made of fire streams and one cement reserroir from which numerous anopheline larræ had been taken in the course of a mosquito surrer in September and October, 1915, br Epidemiologist Griffitts of the serrice. Sereral Culex egg boats and cast puparia were collected, but neither eggs nor larræ of Anopheles were seen. Two trained observers from this locality reported that dereloped larræ and pupæ of Anopheles were seen in protected streams in Norember, and as late as the last week of December, 1915.

Specimens of Anopheles punctipennis and quadrimaculatus were caught, on the first erening of the inrestigation (Jan. 3) while biting cattle. The temperature at this time was $21^{\circ} \mathrm{C}$. General infestation at this place had been seen a few dass previousls when an unusual rise in temperature had been recorded.

Some idea of at least the maximum temperature during the surres at this place can be gained from the following table:

Table No. III.

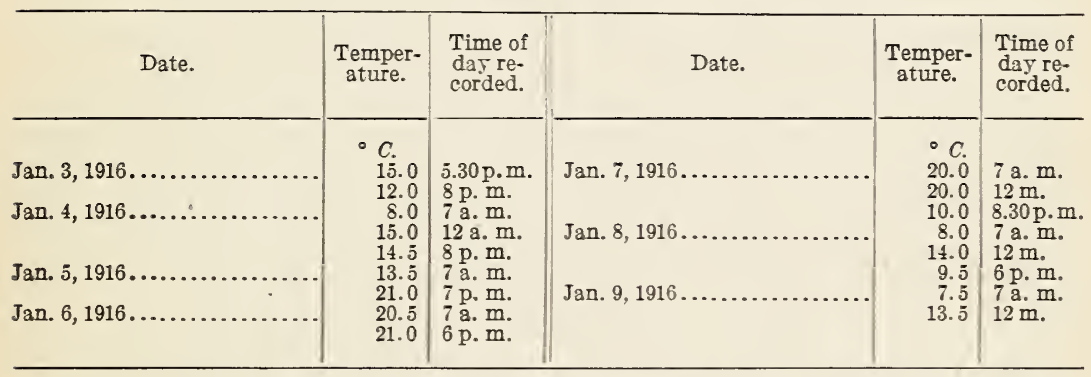

The following table enumerates the distribution of the 392 anophelines collected in this locality, January 3 to 9, 1916:

TABLE No. Ir.-Giving the distribution of Anopheles found in Talladega Springs, Ala.

\begin{tabular}{|c|c|c|}
\hline \multirow[b]{2}{*}{ Location. } & \multicolumn{2}{|c|}{$\begin{array}{l}\text { Number of mos- } \\
\text { quitoes. }\end{array}$} \\
\hline & $\begin{array}{l}\text { A. punc- } \\
\text { tipennis. }\end{array}$ & $\begin{array}{l}\text { A. quad- } \\
\text { rimacula- } \\
\text { tus. }\end{array}$ \\
\hline 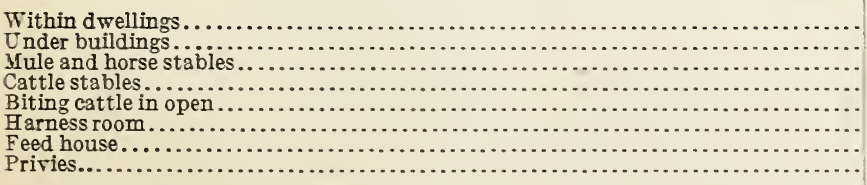 & $\begin{array}{r}7 \\
27 \\
81 \\
159 \\
6 \\
4 \\
75 \\
26\end{array}$ & 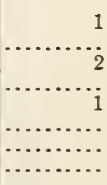 \\
\hline 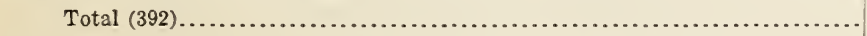 & 385 & 4 \\
\hline
\end{tabular}

Dissections were made of 371 specimens collected. No organisms resembling Plasmodium were found. It is interesting to note in this connection that mosquitoes which have been interrupted in their hiber- 
nation can be induced to bite malarial patients and prove efficient hosts for the infective sporozoites. This was indicated in a series of experiments made with some of the specimens collected at Talladega Springs. This occurred six reeks after they were subjected to the artificial conditions of the New Orleans laboratory.

The results of dissecting 2,122 specimens of Anopheles in the Mississippi series hare been reported in a prerious paper. (Mitzmain, 1915.)

A total of 1,211 specimens was dissected previous to May 15, after which time infected mosquitoes in nature rere found. It is of course realized that this lot may possibly include individuats of the spring brood, but unless infections are involved it is found convenient to include them. In this connection it is pointed out that the opportunity for receiving the initial infection farors the rejurenated winter forms, which are the first to secure blood previous to egg laying and the death of the brood.

The 1,211 specimens were distributed as to species as follows:

A. quadrimaculatus, $1.08+$ specimens.

A. punctipennis, 97 specimens.

A. crucians, 30 specimens.

The remaining mosquitoes dissected during the month of May were used as indicators of the first appearance of the sporogonic cycle of the malaria parasite for this district. These included 902 specimens of A. quadrimaculatus and 9 specimens of A. punctipennis. None of the latter became infected, but 3 specimens of A. quadrimaculatus showed malaria organisms between May 15 and May 26.

It has been previously stated that the occasional sporadic flight and consequent activity of Inopheles mosquitoes were witnessed early in the investigation during February 11-14. Upon the first day of the mosquito attacks the maximum temperature had risen $6.5^{\circ}$ C.- from $12.5^{\circ} \mathrm{C}$. of the previous day to $19^{\circ} \mathrm{C}$. - which rise continued for the three following dars to a maximum of $21^{\circ} \mathrm{C}$.

When men and horses were exposed in the woods the biting appeared general without apparent host preference. House infestation was reported to be unusually serere, although complaints by the plantation negroes were not generally credited. Besides dissecting as many captured specimens as possible, during the intervals of collecting an effort was made to ascertain the pathogenic effect, if any, of the biting of the infesting Anopheles. Fifteen persons besides myself complained of the biting of mosquitoes upon this occasion, and the subsequent medical histories of these individuals were accurately followed for a period of four-fire weeks. No case of clinical malaria dereloped in any of these persons: none of them was using quinine in any form. From this time, extending through March and April, four reliable observers, technically trained or col- 
lege-bred men, reported occasional attacks of Anopheles mosquitoes. They remained clinically and microscopically negative for malaria.

During the four months of the investigation a total of 49 cases of clinical malaria came under personal observation. The blood from 35 of these cases was examined microscopically and definitely determined as to type. Not a single instance of new infection was established, all of the persons affected haring been ill during December, 1914-January, 1915, and proved to have relapsed. In sereral, with severē paroxysms, plasmodial gametocytes were found.

Since it seems fair to assume that hibernating Anopheles in this region can be excluded as winter carriers of malaria, we may turn to the consideration of the rôle assumed by man in perpetuating this disease.

It seemed desirable, in making a parallel study of this nature, to include as many human beings as the number of mosquitoes dissected. This I have succeeded in doing by a collection of blood specimens made from persons most likely to hare been exposed to the bites of the mosquitoes examined. This index, to be of practical value, had to be completed while mosquitoes were still hibernating and previous to the general flight.

This was done during the months of February and March, 1915. It was aimed to obtain as many blood specimens as practicable from the persons living on plantations and clearings, where the bulk of mosquitoes had also been collected. The majority of the blood specimens were made from colored and white persons while at work clearing timber, burning trees, making ditches, and tilling preparatory to planting the cotton crop. Likewise homes, stores, and offices were visited, in addition to the facilities offered by the company's physicians in obtaining blood smears from patients and risitors.

A total of 1,184 blood specimens was collected from these sources and the character of the persons examined as well as the results are tabulated below:

TABLE No. V.-Showing persons examined in February-March, 1915.

\begin{tabular}{|c|c|c|c|c|c|c|c|c|c|c|}
\hline \multirow{3}{*}{ Age (years). } & \multicolumn{5}{|c|}{ Number examined. } & \multicolumn{5}{|c|}{ Number infected. } \\
\hline & \multicolumn{2}{|c|}{ White. } & \multicolumn{2}{|c|}{ Colored. } & \multirow{2}{*}{ Total. } & \multicolumn{2}{|c|}{ White. } & \multicolumn{2}{|c|}{ Colored. } & \multirow{2}{*}{ Total. } \\
\hline & Mf. & F. & M. & F. & & M. & F. & M. & F. & \\
\hline 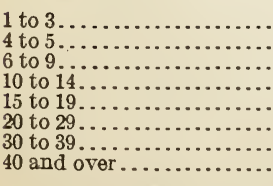 & \begin{tabular}{r|}
7 \\
7 \\
9 \\
8 \\
6 \\
18 \\
27 \\
13 \\
\end{tabular} & $\begin{array}{r}6 \\
3 \\
7 \\
4 \\
2 \\
14 \\
19 \\
5\end{array}$ & $\begin{array}{r}12 \\
15 \\
27 \\
75 \\
86 \\
135 \\
114 \\
170\end{array}$ & $\begin{array}{r}13 \\
9 \\
31 \\
60 \\
46 \\
107 \\
45 \\
84 \\
\end{array}$ & \begin{tabular}{r|}
38 \\
34 \\
74 \\
147 \\
140 \\
274 \\
205 \\
272 \\
\end{tabular} & $\begin{array}{l}8 \\
2 \\
2 \\
5 \\
1 \\
9 \\
8 \\
7\end{array}$ & $\begin{array}{r}1 \\
1 \\
1 \\
\cdots \\
1 \\
4 \\
6 \\
2\end{array}$ & $\begin{array}{l}\cdots \\
41 \\
41 \\
43 \\
74 \\
42 \\
72\end{array}$ & $\begin{array}{r}7 \\
3 \\
9 \\
23 \\
22 \\
43 \\
16 \\
14\end{array}$ & $\begin{array}{r}16 \\
10 \\
33 \\
69 \\
67 \\
130 \\
72 \\
95 \\
\end{array}$ \\
\hline Total........... & $\overline{95}$ & 60 & 634 & 395 & 1,184 & 42 & 16 & 297 & 137 & 492 \\
\hline
\end{tabular}


TABLE No. VI.-Summary of results of blood examinations. February-3farch, 1915.

Total persons examined

1,184

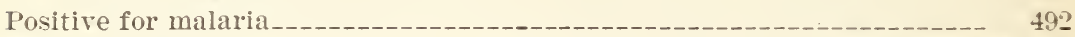

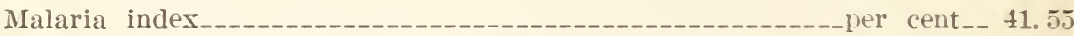

Omitting mixed cases and one quartan:

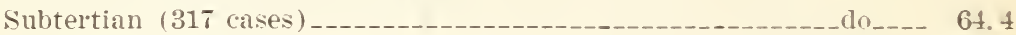

Tertian (166 cases) -

Number of gametocyte carriers__________- 122

Subtertian cases with gametocrtes

Tertian cases with gametocrtes._-_._- 15

Percentage of malarial cases with gametocyter__-_-_-_-_-_-_per cent_- 24. S

Cases of quartan

Cases of mixed infections (exclucled in the tertian and subtertian totals) - $S$

Classification of microscopical findings.

Scanty,+ 1 organism per 40 fields and over

Few ++ , 1 organism per 25 fields

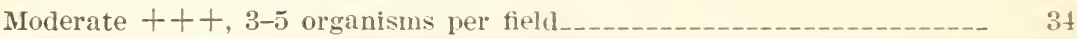

Numerous,$++++ 6-10$ organisms per field + -

It will be seen from the summary of results of blood examinations that a sufficient number, nearly one-fourth, of the persons found infected harbored the sexual parasites. Material was thus provided for mosquitoes to carry on the spring cycle of new infections. This state of affairs was no doubt continued uninterruptedly, as it was observed that relatively few of the human carriers were aware of, or were concerned about, their infections.

An insidious condition faroring mosquito transmission thus existed here, as little or no efficient protection against mosquito transmission was provided. Of the total number of infections, namely, 492 persons, only 35 persons were known to develop active symptoms subsequent to taking this index. In addition to these, 14 cases of clinical malaria were reported, but not included in the total infected, as they were not examined by the writer.

The latent character of the infection may be appreciated in the prolonged search for the parasites in many of the blood smears examined. In 456 thick-blood films organisms were scanty or few, and in 258 thick films they were exceedingly scanty. and if corresponding thin films had been examined would doubtless hare been found negative.

The parasitological conditions present shortly preceding the time when the mosquitoes sought places for hibernation can best be shown in a malaria index of the persons living in this region during the fall of 1914. The table following shows the results of examinations of 1,666 persons residing in the various plantations in which hibernation studies were conducted. The malaria survey which it rep- 
resents was conducted in September, 1914, under the direction of Surg. R. H. von Ezdorf, in charge of malaria investigations of the Public Health Service until his death in September, 1916, and be also personally supervised the microscopical examinations tabulated.

TABLE No. VII.-Showing persons examined in September, 1914.

\begin{tabular}{|c|c|c|c|c|c|c|c|c|c|c|}
\hline \multirow{3}{*}{ Age. } & \multicolumn{5}{|c|}{ Number examined. } & \multicolumn{5}{|c|}{ Number infected. } \\
\hline & \multicolumn{2}{|c|}{ White. } & \multicolumn{2}{|c|}{ Colored. } & \multirow{2}{*}{ Total. } & \multicolumn{2}{|c|}{ White. } & \multicolumn{2}{|c|}{ Colored. } & \multirow{2}{*}{ Total. } \\
\hline & M. & F. & M. & F. & & M. & F. & M. & F. & \\
\hline 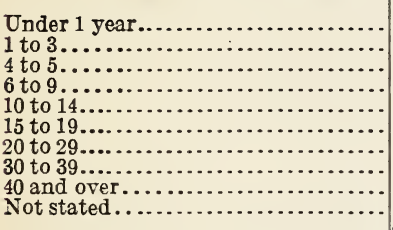 & $\begin{array}{c}1 \\
1 \\
\cdots \\
\cdots \\
3 \\
1 \\
1 \\
1\end{array}$ & $\begin{array}{r}\cdots \\
1 \\
1 \\
\cdots \\
1 \\
1 \\
\cdots \\
4\end{array}$ & $\begin{array}{r}1 \\
26 \\
42 \\
73 \\
119 \\
92 \\
200 \\
112 \\
242\end{array}$ & $\begin{array}{r}2 \\
22 \\
37 \\
66 \\
94 \\
86 \\
196 \\
86 \\
151 \\
3 \\
\end{array}$ & $\begin{array}{r}3 \\
48 \\
80 \\
140 \\
215 \\
178 \\
400 \\
200 \\
394 \\
8\end{array}$ & $\begin{array}{c}\cdots \\
1 \\
1 \\
\cdots \\
1 \\
1\end{array}$ & 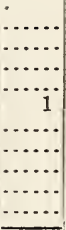 & $\begin{array}{r}1 \\
17 \\
18 \\
30 \\
42 \\
42 \\
73 \\
44 \\
94 \\
2 \\
\end{array}$ & $\begin{array}{r}8 \\
13 \\
34 \\
30 \\
35 \\
85 \\
44 \\
62 \\
2 \\
\end{array}$ & $\begin{array}{r}1 \\
25 \\
32 \\
64 \\
74 \\
77 \\
160 \\
89 \\
156 \\
4\end{array}$ \\
\hline Total & 7 & 8 & 907 & 743 & 1,666 & 5 & 1 & 363 & 313 & 682 \\
\hline
\end{tabular}

Summary of results of blood examinations-September, 1914.

Total number of persons examined 1. 666

Positive for malaria_____- 682

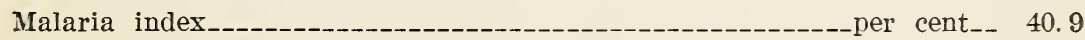

Types :

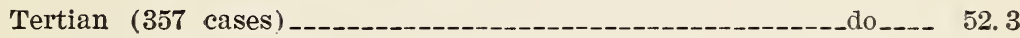

Subtertian (319 cases) --_-_-_-_-_-_-_-_-_-_-_-_-_-_-_do_-_- 47.7

Mixed cases (6) not considered in the percentage above.

Number of subtertian gametocyte carriers.

Percentage of subtertian gametocyte carriers

-per cent_-

26.4

In comparing the data obtained in September, 1914, with those obtained in February and March, 1915, it is erident that the malaria index existing during the winter months remains little altered. It is patent, at least, that recoreries following treatment do not favorably influence the important bearing of the gametocyte carrier. It will be observed that not only is there a relative increase in the number of subtertian gametocyte carriers, but an actual increase, the percentage being raised during latency from 26.4 per cent to 32.8 per cent, and the total number is increased from 86 to 122 . It must be obserred, however, in this connection, that probably a smaller percentage of the winter carriers harbored suitable numbers of gametocytes to be capable of infecting Anopheles mosquitoes.

Of the total number of 1,184 persons examined in February and March, 1915, it is possible to draw certain comparative deductions from a representatice group of 103 carriers of all ages distributed among 11 plantations. The persons in this group were selected be- 
cause they had been examined preriously in September, 1914, and, with few exceptions, had not changed their place of residence. It was found that none of the 103 persons had receired specific treatment, so that the recoreries (so far as the microscopical findings can demonstrate) were spontaneous, and the continued presence of parasites could be ascribed either to relapses or to latent infections. In this group 48 cases were found still to harbor the malaria organisms, while the remaining 55 were negative at the time of the reexamination. The positive cases were distributed as follows:

Thirty-three (6S.7 per cent) subtertian, of which 14 harbored gametocrtes.

Fifteen (31.3 per cent) simple tertian, of which one harbored gametocrtes.

It is of interest to note that $\delta$ of the 15 gametocrte carriers were also crescent carriers in September, 1914.

These 15 infected persons, according to the medical records of the plantation health officer, showed no clinical srmptoms of the disease during the winter period.

The importance of the public health relation of gametocyte carriers was brought viridly to the attention of the investigator in the discovery of three infected Anopheles quadrimaculatus in dwellings which were definitely proved to contain indiriduals harboring gametocytes. These persons are included amongst the eight infected with gametocytes in September, 1914, and again in March, 1915.

The finding of these infected mosquitoes and the demonstration of the probable human sources of the infection serres to show for this region the intimate relations existing in the perpetuation of the disease through the winter and in linking together the two malarial seasons-autumn and spring.

\section{SEMMARY AND CONCLLSIONS.}

The review of the literature on the orerwintering of malaria organisms in man and mosquito and on the habits of anophelines during hibernation leads to the impression that the conditions found elsewhere are essentially reproduced in the region investigated in the southern part of the United States.

Hibernation studies during Febuary-June, 1915, were made in territory comprising 15 plantations in Bolirar and Washington Counties, Miss., haring a malaria index of orer 40 per cent.

Search for hibernating anophelines was conducted in places commonly known or likely to harbor them. The places inspected included residences, outbuildings, animal sheds. cotton houses, swampy and dry woods. Mosquitoes were found to be generally absent from all places except under houses and in the depth of woods. Interiors of dry hollow trees and those with roots in standing water were deroid of resting anophelines. This was ascertained by the aid of electric torches and by sulphur fumigation. 
Persistent search for anopheline eggs, larræ, and pupæ which might hare hibernated proved fruitless.

The conclusion is drawn that, in this region in northwestern Mississippi, only the adult female mosquito of Anopheles hibernated. Collateral studies made in Alabama gare similar results.

Hibernation data to be of intrinsic ralue must insure absence of fresh emergences and consider only the presence of the brood known to have emerged prior to the onset of the cold reather. The characteristics of the hibernating mosquito are indicated by the presence of eggs and abundant stored fat cells in the body of the old female, and by the entire absence of male anophelines. It is concluded that the appearance of male anophelines indicates recent emergences, and is interpreted to indicate the arrival of the spring brood.

A control of field observations concerning laving of eggs during winter was prorided by laboratory experiments with Anopheles quadrimaculatus. These laboratory tests gare the information that, with more than 100 apparently gravid females, egg deposition did not take place at temperatures betreen $4.5^{\circ} \mathrm{C}$. and $12.5^{\circ} \mathrm{C}$.

In another laboratory experiment, eggs were laid at temperatures ranging between $13.5^{\circ} \mathrm{C}$. and $16.7^{\circ} \mathrm{C}$., but these did not hatch except at temperatures abore $16^{\circ} \mathrm{C}$.: the optimum established being at temperatures between $19^{\circ} \mathrm{C}$. and $21^{\circ} \mathrm{C}$. These experimental data, applied to conditions found to exist in the region studied, would provide for egg deposition and hatching beginning April 21, when a mean temperature of orer $16^{\circ} \mathrm{C}$. was sustained. This fits in perfectly with an experimental case in which a hibernating female Anopheles, caught April 10, 1915, was induced to bite and laid eggs April 16, which hatched April 21.

Hibernation conditions were obserred in January, 1916, in the State of Alabama at a point haring the same latitude as Bolivar County, Miss. Probably the conditions found here are more representative for the southern United States. Stables in which cattle and horses were housed for the winter yielded more resting anophelines than elsewhere. A total of 371 specimens of Anopheles was collected here and, upon dissection, was found negative for malaria parasites.

It was ascertained, during the course of the winter studies in the region inrestigated, that occasional biting of roused hibernating Anopheles did not hare any pathogenic significance, and all of the clinical malarial infections occurring in this region during this period were prored to be recurrences of former attacks.

It was concluded that hibernating anophelines, collected in the region inrestigated, did not harbor parasites of malaria. This was determined after an examination of 2,122 dissected anophelines, of which 1,211 specimens were examined before May 1ð, 1915. Among 
the remaining 911 specimens, serving as a malaria indicator for the spring season, 3 mosquitoes between May 15 and May 26, were definitely shown to contain oocysts, indistinguishable from those seen in mosquitoes experimentally infected with human malaria.

In the investigation of man as the responsible winter carrier, 1,184 persons, residing on the plantations selected, were examined for malaria parasites. Four hundred and ninety-two infections were identified microscopically; 317 cases were of the subtertian type, 8 were mixed infections, and the remainder were of the simple tertian type, with the exception of one quartan case.

In the consideration of these infections an important fact stands out: nearly one-fourth (24.8 per cent) of the human carriers harbored gametocytes.

It was proved that from a group of 103 persons, examined in March, 1915, 8 of the 15 gametocyte carriers identified, were similarly infected during the preceding fall.

The incrimination of man as the sole winter carrier is emplasized by the fact that 3 malaria-infected Anopheles quadrimaculatus were found in the homes of these gametocyte carriers during May 15 to May 26, previous to which time 1,180 specimens of Anopheles from this source were found to be negative.

ACKNOWLEDGMENT.

The writer wishes to acknowledge his appreciation to the various officials of the Mississippi Delta Planting Co. for the material assistance rendered in the collection of data for this study. Through the kindly services of the general manager, Prof. Fox, and his assistant, Mr. Young, the cooperation of the plantation managers was obtained in securing blood specimens. The temperature chart and the sketch map of the plantations were obtained through the assistance of these gentlemen. Acknowledgment is likewise made to Dr. Miller and Dr. Lane, of the medical staff, for their intelligent cooperation at all times. Thanks are due the chief medical officer, Dr. Miller, for providing generous laboratory facilities and offering personal assistance in collecting mosquitoes and in securing blood specimens. 


\section{REFERENCES TO THE LITERATURE.}

Annett, H. E., and Dutton, J. E. (27 Apr., 1901). A Preliminary Note on the Hibernation of Mosquitoes. Brit. Med. Journ., p. 1013.

Austen, E. E. (Mar., 1901). The Genus Anopheles. The Practitioner, vol. 66, No. 393 , p. 343 .

Craig, C. F. (1909). The Malarial Ferers. (New York, William Wood \& Co.) p. 69:

Deaderick, W. H. (1911). Practical Study of Malaria. (Philadelphia, W. B. Saunders Co.) p. 71.

Giles, G. M. (1902). A Handbook of the Gnats or Mosquitoes, 2d ed. (London, John Bale, Sons \& Danielsson, Ltd.) p. 141.

Henson, Graham E. (1913). Malaria. (St. Louis, C. V. Mosby, Comp.) p. 121.

Herms, W. B. (1915). Medical and Veterinary Entomology. (New York, Macmillan Co.), pp. 112, 113.

Howard, L. O., Dyar, H. G., Knab, F. (1912). The Mosquitoes of North and Central America and the West Indies (Washington, D. C., Carnegie Institution), pp. 119, 120.

Manson, Patrick (Mar., 1901). Etiology, Prophylaxis, and Treatment of Malaria. The Practitioner, vol. 66, No. 393, p. 256.

Manson, Patrick (1914). Tropical Diseases, 5th ed. (London, Cassell \& (o.) p. 102.

Mitchell, E. G. (1907). Mosquito Life. (New York, G. P. Pu.tnam Sons.) p. 94 .

Mitzmain, M. Bruin (16 July, 1915). Anopheles as a Winter Carrier of Plasmodium. (Reprint No. 290, from the Public Health Reports.)

Nuttall, G. H. F., and Shipley, A. E. (1901). Studies in Relation to Malaria. Journal of Hygiene, Vol. I, No. 3, p. 451.

Patton, W. S., and Cragg, F. W. (1913). A Textbook of Medical Entomology. (London, Christian Literature Society for India.) p. 259.

Rosenau, M. J. (1913). Preventire Medicine and Hrgiene. (New Fork and London, D. Appleton \& Co.) p. 202.

Scheube, B. (1902). The Diseases of Warm Countries. A Handbook for Medical Men, 2d ed. (Philadelphia, P. Blackiston's Son \& Co.), pp. 115, 116.

Smith, J. B. (Feb., 1904). The Common Mosquitoes of New Jersey. New Jersey Agricultural Experiment Station Bulletin 171, p. 32.

Stephens, J. W. W. (1908). Malaria in its Relation to the Mosquito. Nothnagel's Encyclopedia of Practical Medicine, American Edition, pp. 204, 205.

Von Ezdorf, R. H. (1915). Malaria. Reference Handbook of the Medical Sciences. (New York, Wm. Wood Co.) Vol. VI, p. 211. 



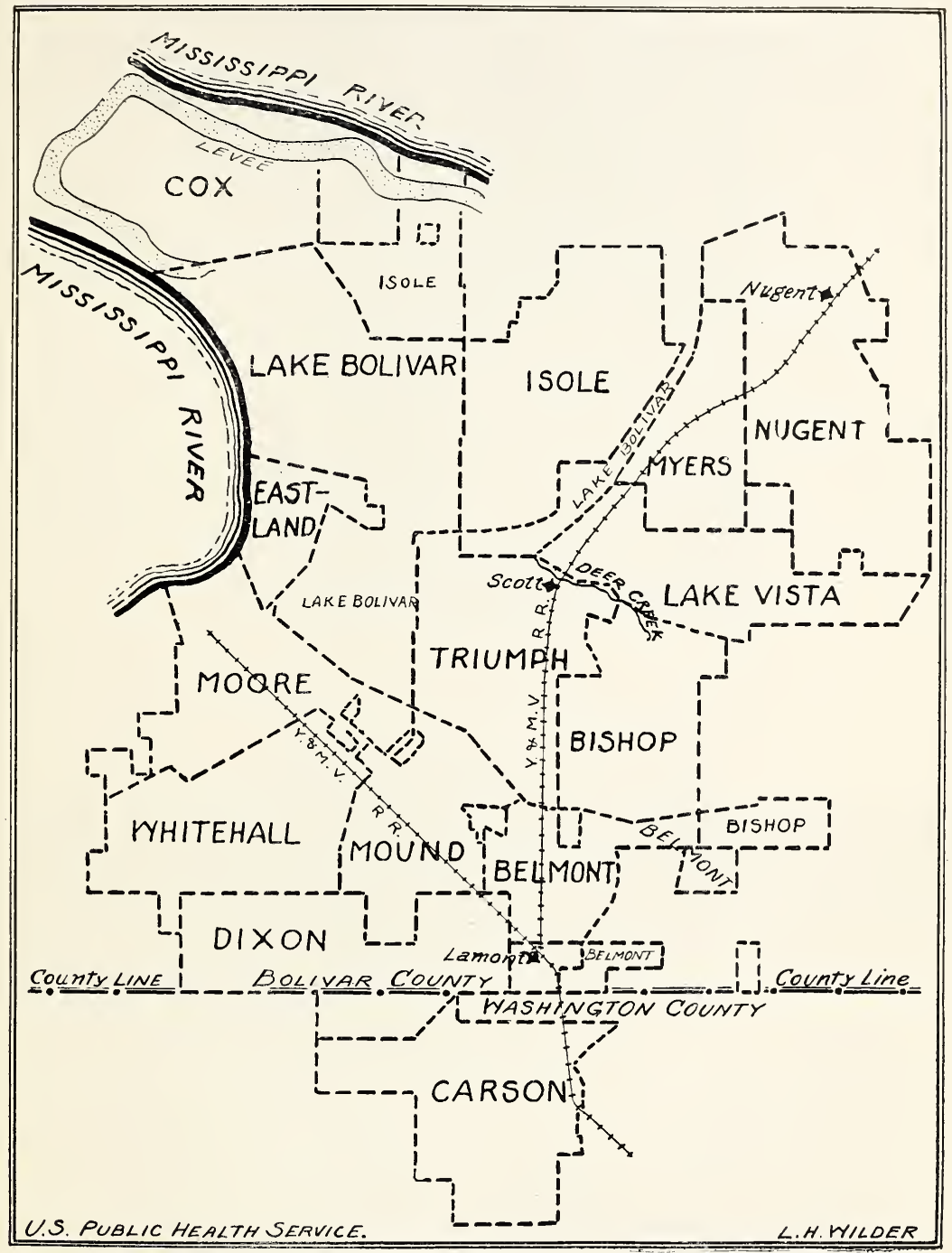

Fig. 1.-Map showing individual plantations of Mississippi Delta Planting Co. 
Public Health Bulletin No. 84.

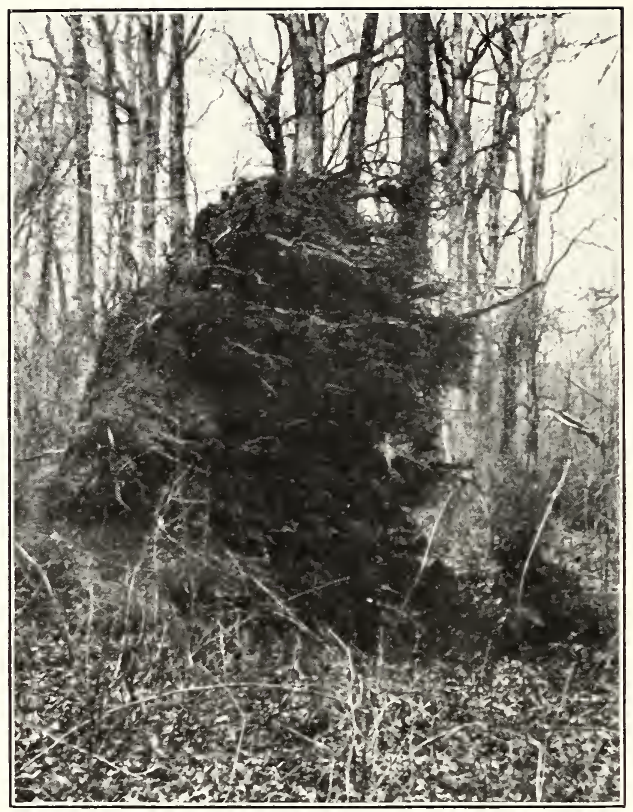

Fig. 2.-Upturned root mass of fallen tree where a few specimens of $A$. quadrimaculatus were found among the exposed root fibers on March 28.

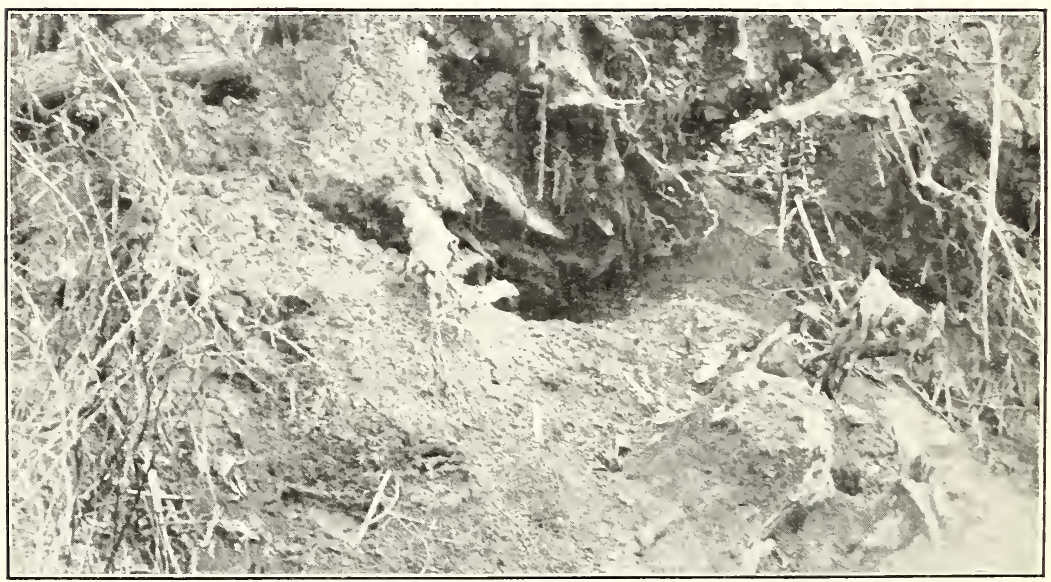

Fig. 3.-Excavation made by falling tree, exposing roots, pool of water beneath. Here in February and March culicines were found in larval and pupal stages and emergences observed. Anopheles absent. 
Public Health Bulletin No. 84.
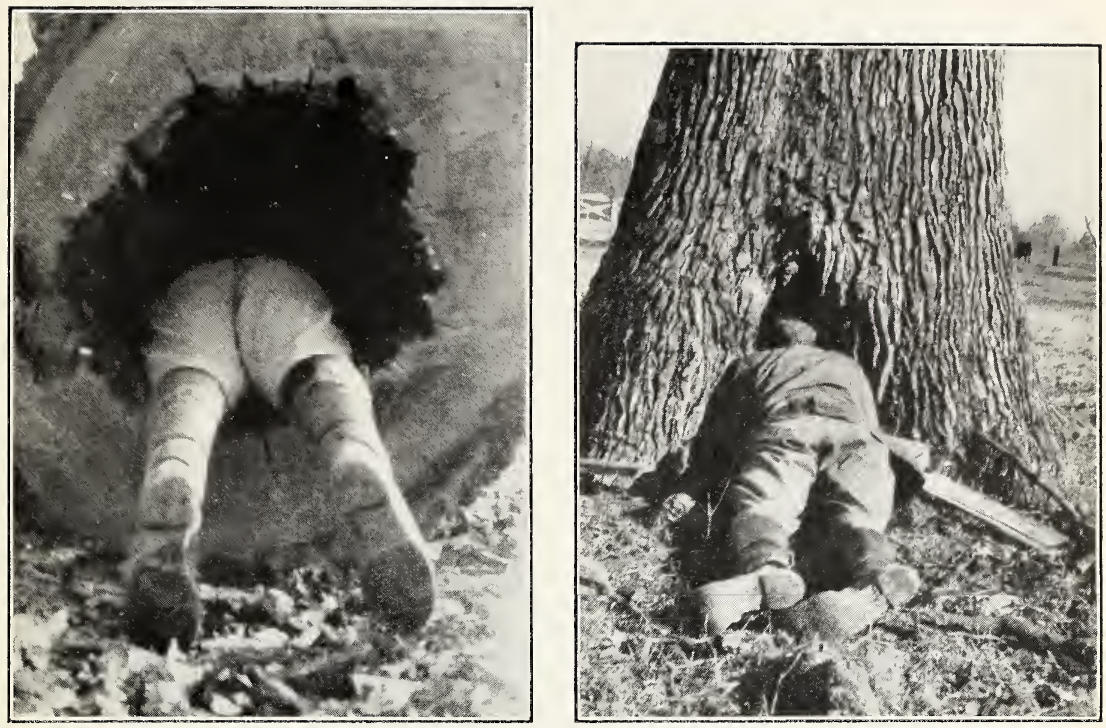

Figs. 4 and 5.--Showing method of searching hollows, in standing and fallen timber, for hibernation forms. The tree shown in figure 5 was seen to harbor many Anopheles in September, 1914.

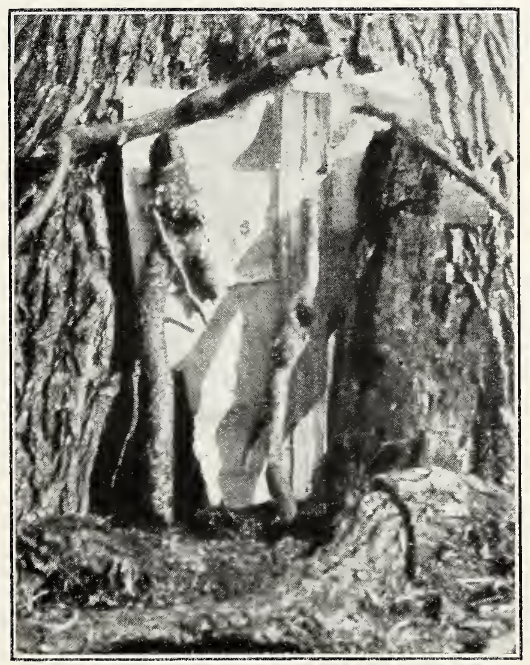

Fig. 6.-A hole in a hollow tree receiving sulphur dioxide fumigation. 
Public Health Bulletin No. 84.

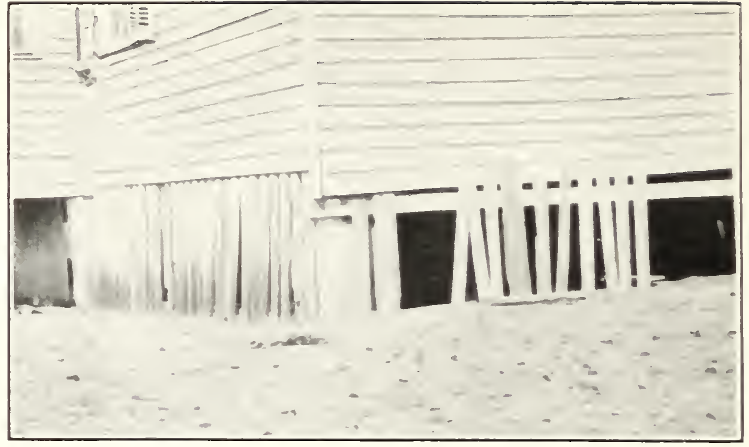

Fig. 7.-Showing understructure of plantation houses, which were found to be fruitful sources of hibernating $A$ nophelcs.

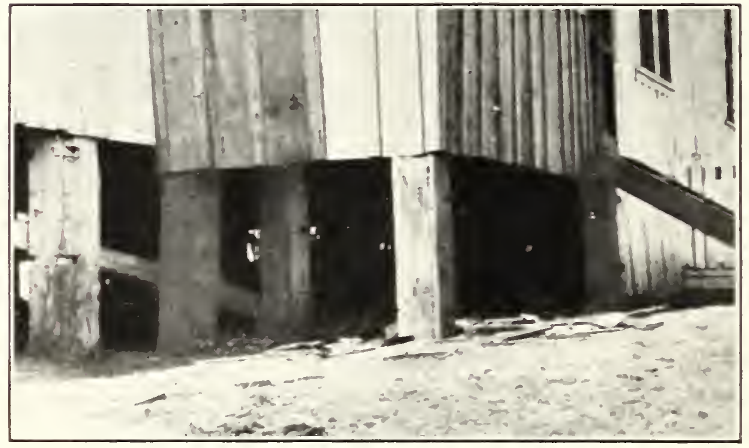

Fig. 8.-Showing understructure of plantation houses, which were found to be fruitful sources of hibernating $A$ nophclcs.

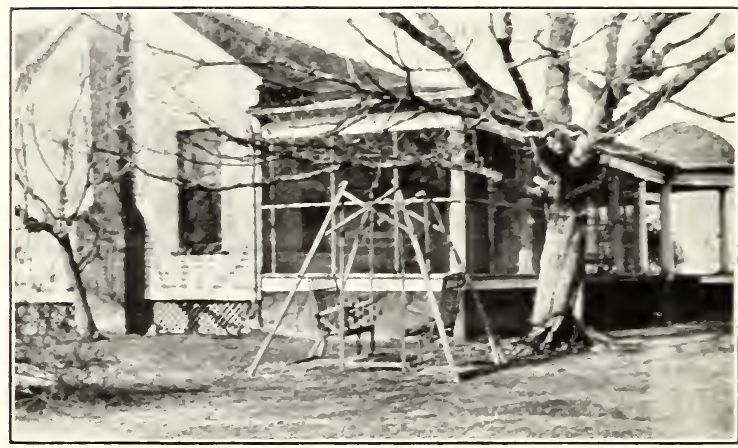

Fig. 9.-Mr. M.'s house, showing means of access by mosquitoes through lattice work and holes in brick understructure. Under this house the first hibernating $A$ nopheles were collected during the first week of February. 
Public Health Bulletin No. 84.

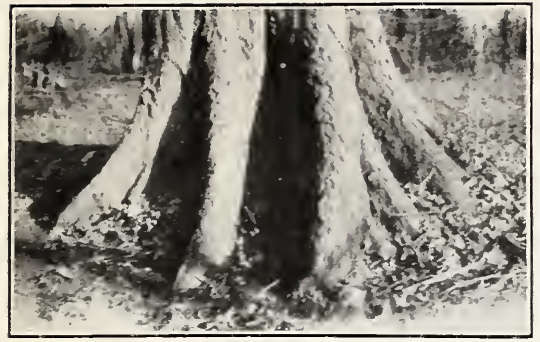

Fig. 10.-Typical cypress trunk with fissured structure in which leaves found lodgment to serve as possible hiding places for resting anophelines. Such places were not found to shelter mosquitoes.

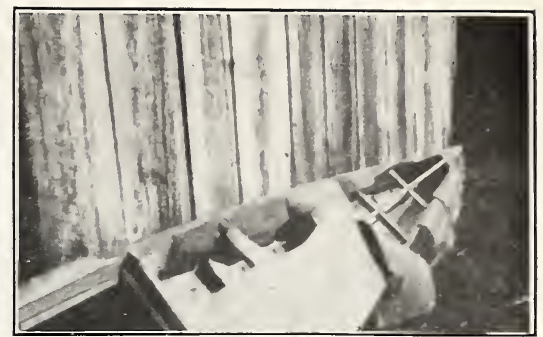

Fig. 11-Canvas covered canoe, which remained undisturbed during fall and winter. Shows the ripped canvas in the end of the canoe where several inches of water remained. No mosquitoes of any stage were seen.

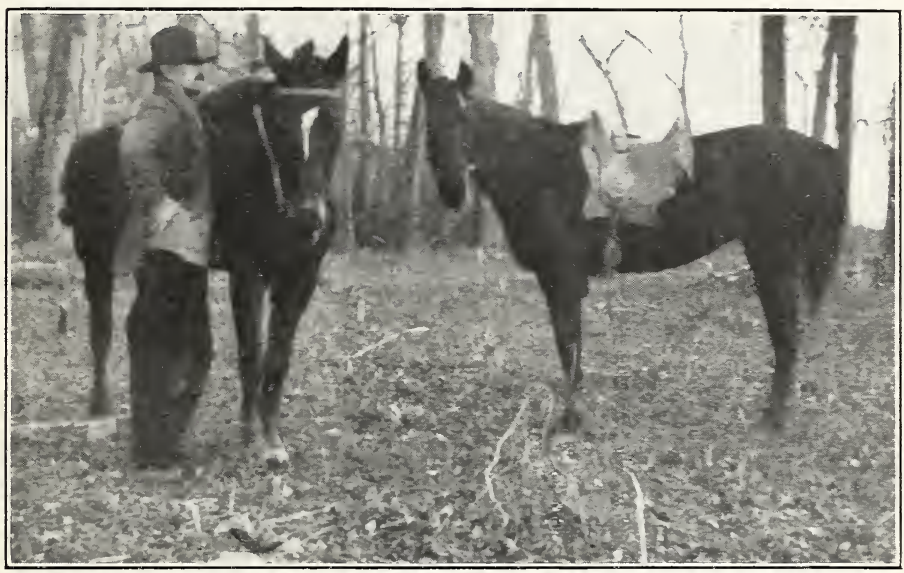

Fig. 12.-Showing the method adopted by use of horses as bait to attract anophelines in the woods.

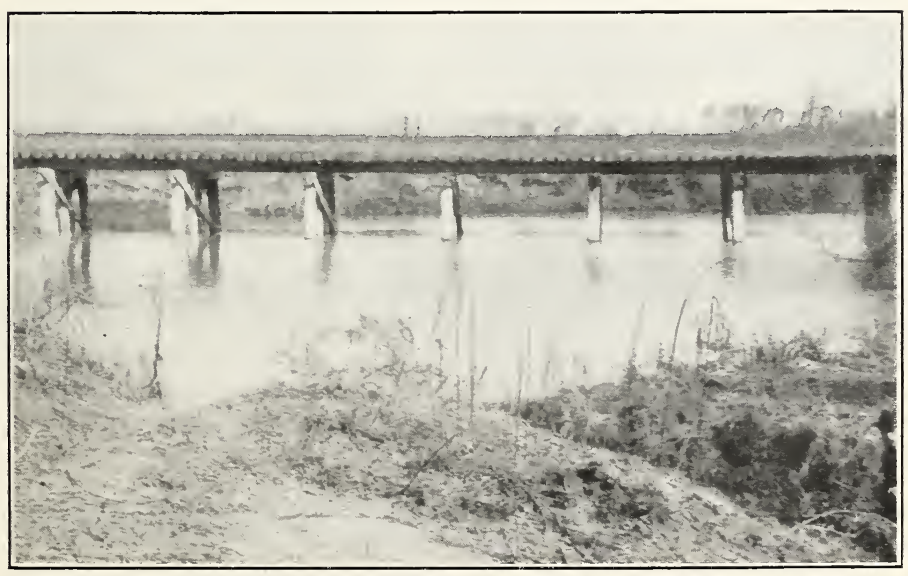

Fig. 13.-An inundated "borrow pit" on Whitehall plantation. Anopheles larvae were not found here during February. 
Public Health Bulletin No. 84.

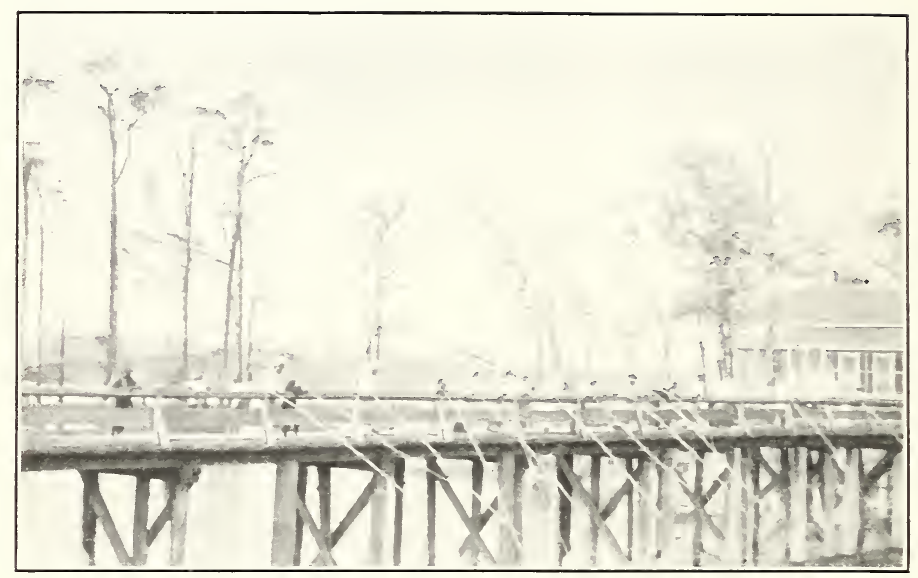

Fig. 14.-Junction of Deer Creek and Lake Bolivar where in late fall larvae and pupae of A.quadrimaculatus were found. Seven persons among the fishing women on the bridge proved to be winter carriers of Plasmodium.

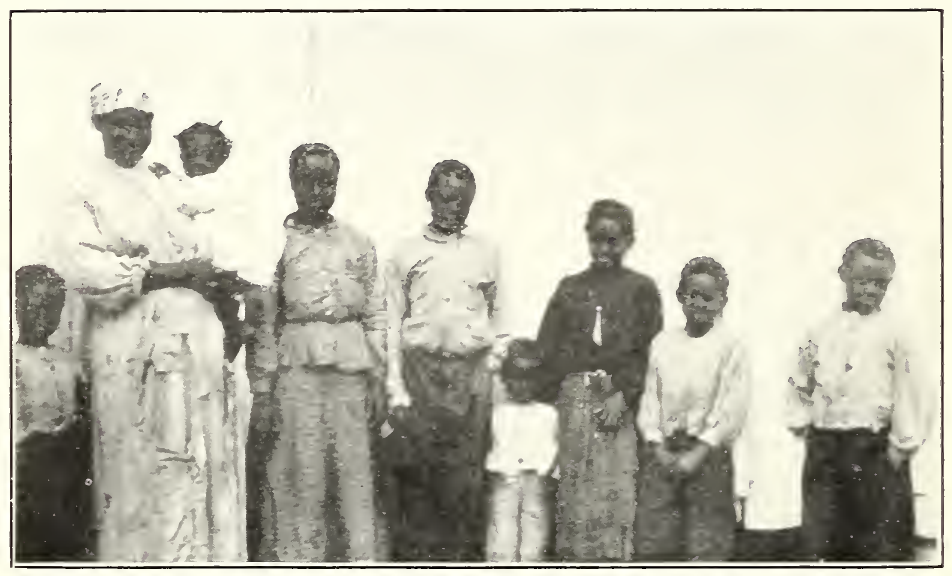

Fig. 15.-Group of negro tenants on Lake Vista plantation. No case of sickness reported here, yet 43 per cent were carriers of malaria during February and March. 
Public Health Bulletin No. 84.

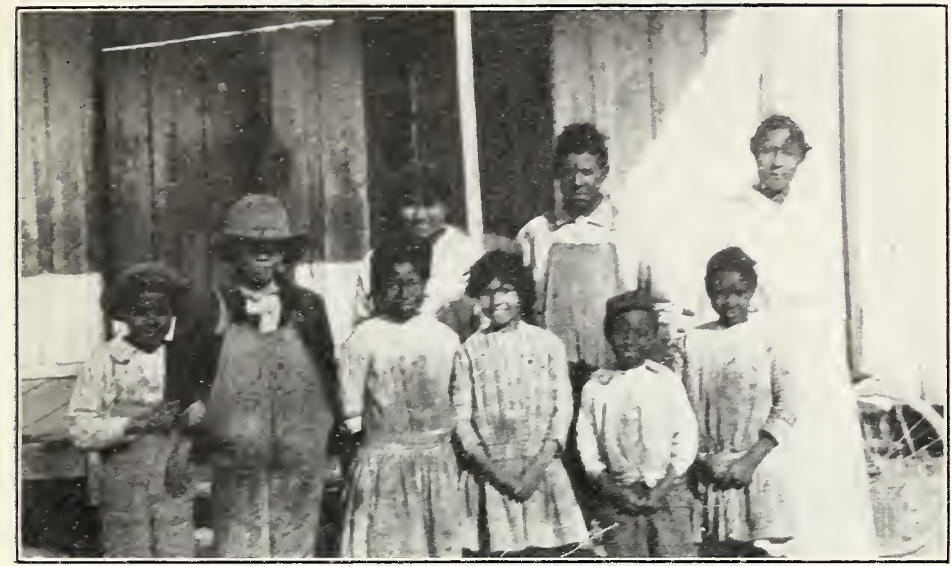

Fig. 16.-Group of tenants on Myers plantation. Fifty percent were infected with malaria during February and March. No clinical case observed. The head of the family proved to be a gamete carrier.

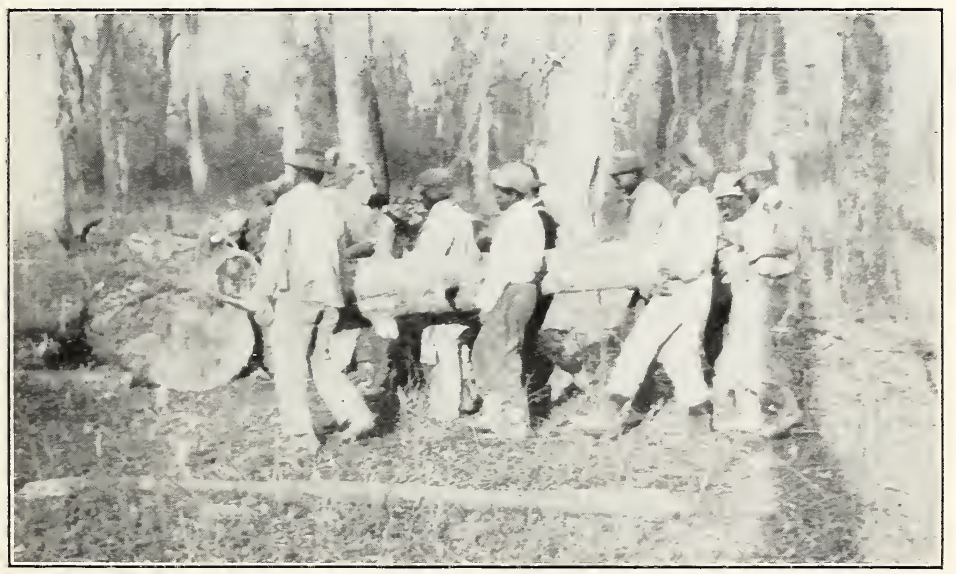

Fig. 17.-Showing apparently healthy negro tenants of Mound plantation engaged in clearing operations. Five of the eight men in this picture were winter carriers of malaria; two of these harbored gametocytes. 
Public Healtn Bulletin No. 84.

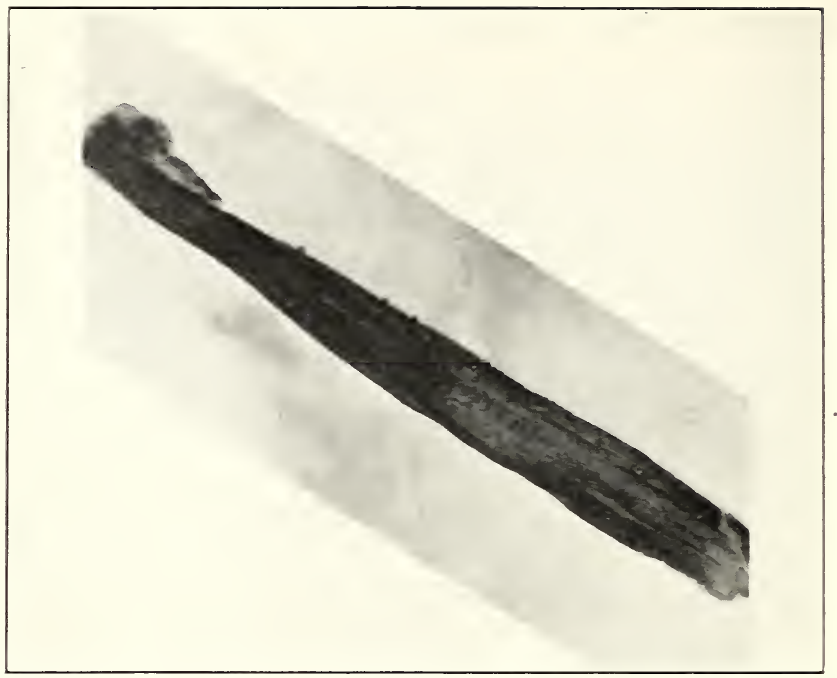

Fig. 18.-Photomicrograph of a stained preparation showing young oocysts on the stomach of an A.quadrimaculatus dissected May 15, 1915. This represents the initial infection of the spring season.

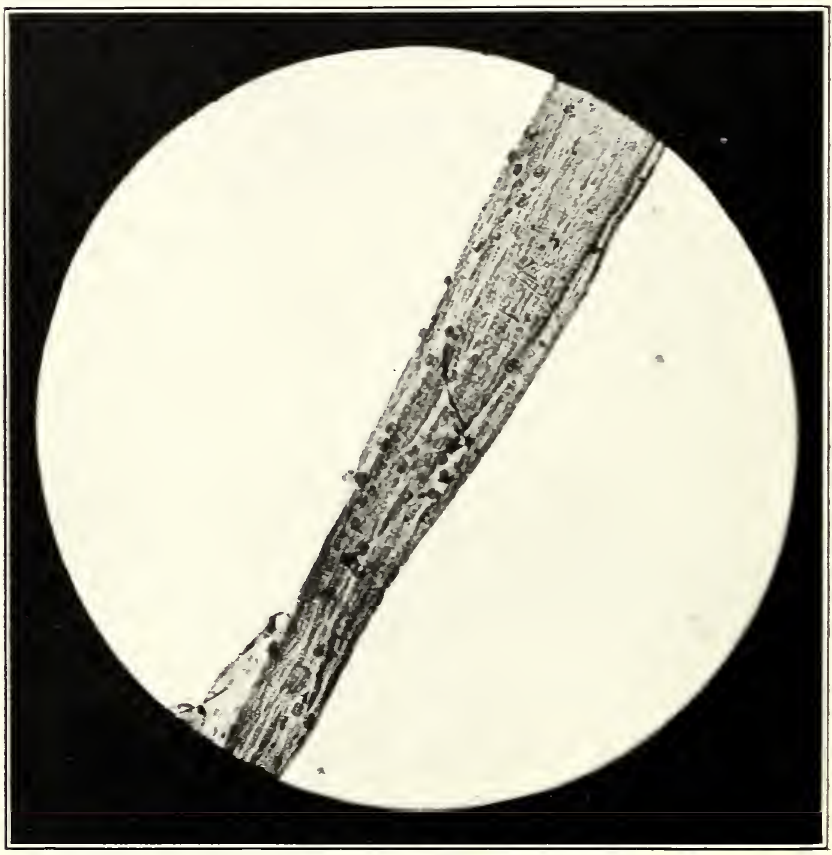

Fig. 19.-Enlarged view of portion of Fig. 18. 


\title{
RELATED PUBLICATIONS.
}

\section{AVAILABLE REPRINTS OR BULLETINS ON MALARIA ISSUED BY THE PUBLIC HEALTH SERVICE, FROM WHICH COPIES MAY BE OBTAINED WITHOUT COST.}

\author{
PUBLIC HEALTH BLLLETIX.
}

79. Impounded Water. Surress in Alabama and South Carolina during 1915 to determine its effect on prevalence of malaria. $\mathrm{By} \mathrm{H}$. R. Carter, J. A. A. Le Prince, and T. H. D. Griffitts. 1916.

84. Is Mosquito or Man the Winter Carrier of Malaria Organisms? By M. Bruin Mitzmain. December, 1916.

\section{REPRINTS FROM THE PUBLIC HEALTH REPORTS.}

28. Prevention and Destruction of Mosquitoes. By Joseph Goldberger. July $17,1908$.

105. Antimalarial Measures for Farmhouses and Plantations. By H. R. Carter. December 6, 1912.

108. Malarial Ferers-Prevalence and Geographic Distribution in Alabama. By R. H. ron Ezdorf. December 27, 1912.

156. Malaria in North Carolina. Br H. R. Carter. December 19, 1913.

159. Malarial Index Work. Methods used in Obtaining Blood, making Blood Smears and Staining. By R. H. ron Ezdorf. December 26, 1913.

160. Malarial Ferers. Prevalence and Geographic Distribution in Arkansas. By R. H. ron Ezdorf. January 2, 1914.

170. Prerention of Malaria. Suggestions on How to Screen the Home to Keep out Effectirely the Mosquitoes Which Spread the Disease. Br R. H. ron Ezdorf. February 27, 1914.

172. Malarial Ferers. Prevalence and Geographic Distribution in South Carolina, Georgia, and Florida. Br R. H. von Ezdorf. March 13, 1914.

175. Quinine Prophylaxis for Malaria. Br H. R. Carter. March 2ૉ, 1914.

180. Malarial Ferers in the United States. By R. H. ron Ezdorf. April 10, 1914.

186. Malarial Ferers. Prevalence and Geographic Distribution in Alabama. By R. H. ron Ezdorf. May 1, 1914.

193. Malarial Ferer. Preralence and Geographic Distribution in Mississippl, 1913. By R. H. ron Ezdorf. May 22, 1914.

217. Mosquitoes and Malaria. Report on a Short Trip in Eastern North Carolina. By Ch. Wardell Stiles. September 4, 1914.

214. Impounded Water. Some General Considerations on its Effect on the Prevalence of Malaria. By H. R. Carter. December 25, 1914.

248. Impounded Waters. Their Effect on the Prevalence of Malaria-Surrey at Blewetts Falls. Bг H. R. Carter. January 1, 1915.

257. Impouuded Waters. A Study of Such Waters on the Coosa Rirer in Shelby, Chilton, Talladega, and Coosa Counties, Ala., to Determine the Extent to which They Affect the Production of Anophelines, and of the Particular Conditions which Increase or Decrease their Propagation. By J. A. A. Le Prince. February 12, 1915. 
258. Malaria Control. Drainage as an Antimalarial Measure. By J. A. A. Le Prince. February 19, 1915.

260. Control of Malaria. Oiling as an Antimosquito Measure. By J. A. A. Le Prince. February 26, 1915.

272. Anopheline Surveys. Methods of Conduct and Relation to Antimalarial Work. By R. H. von Ezdorf. April 30, 1915.

277. Malaria in the United States. Its Prevalence and Geographic Distribution. By R. H. von Ezdorf. May 28, 1915.

290. Anopheles as a Winter Carrier of Plasmodium. The Mosquito as a Prophylactic Indicator. By M. Bruin Mitzmain. July 16, 1915.

324. Anopheles Punctipennis Say. Its Relation to the Transmission of Malaria. Report of Experimental Data relative to Subtertian Malarial Fever. By M. Bruin Mitzmain. February 11, 1916.

337. Tertian Malarial Fever-Transmission Experiments with Anopheles Punctipennis. By M. Bruin Mitzmain. May 12, 9116.

359. Anopheles Infectivity Experiments. An attempt to Determine the number of persons one Mosquito can Infect with Malaria. By M. Bruin Mitzmain. September 1, 1916.

SUPPLEMENTS TO THE PUBLIC HEALTH REPORTS.

11. What the Farmer Can Do to Prevent Malaria. By R. H. von Ezdorf. February 13, 1914.

18. Malaria-Lessons on its Cause and Prevention. (For use in Schools.) By R. H. Carter. July 17, 1914. 
